\title{
Synthesis of Plakortolides E and I Enabled by Base Metal Catalysis
}

\author{
Stefan Leisering, Alexandros Mavroskoufis, Patrick Voßnacker, Reinhold Zimmer, Mathias Christmann* \\ Institute of Chemistry and Biochemistry, Freie Universität Berlin, Takustraße 3, 14195 Berlin, Germany
}

Supporting Information Placeholder

ABSTRACT: A protecting-group-free synthesis of two endoperoxide natural products, plakortolide $E$ and plakortolide I, is reported. Key-steps feature the use of earth-abundant transition metals, consisting of a vanadium-mediated epoxidation, an iron-catalyzed allylic substitution, and a cobalt-induced endoperoxide formation. Our approach combines redox-economy, chemoselective bond-forming reactions, and telescoping into one-pot operations to forge an overall efficient synthesis.

In synthesis planning, it is desirable to derive the target molecule from a carefully selected starting material through a sequence of successive construction steps with minimal functional group interconversions or protecting-group manipulations. ${ }^{1}$ The concepts of atom, ${ }^{2}$ redox, ${ }^{3}$ step ${ }^{4}$ and pot $^{5}$ economy provide guidelines to evaluate different synthetic approaches and to design an efficient synthesis. ${ }^{6}$ With these considerations in mind, we embarked on developing rapid syntheses of plakortolides $\mathrm{E}$ and I from $(R)$-linalool, a readily available monoterpene with a seven-carbon overlap to the bicyclic core structure of the target including one stereogenic center. Methodologically, we focused on the use of base metal catalysts for some anticipated challenging chemoselective transformations. ${ }^{7}$

Endoperoxides from both terrestrial and marine sources constitute a class of natural products featuring a wide range of unique and often underexplored bioactivities. ${ }^{8}$ For instance, several polyketide-derived endoperoxides such as plakinic acids, plakortides and plakortolides show potential activity as antitumor, antibacterial and antifungal agents. ${ }^{9}$ Furthermore, terpenebased endoperoxides have proven as valuable compounds for combating malaria with artemisinin as the most important lead structure. ${ }^{10}$

The bicyclic 1,2-dioxane-fused butyrolactone plakortolide I (2) and its C6-epimer, plakortolide E (1) were isolated from marine sponges. ${ }^{11,12}$ In 2002, Jung reported the first synthesis of racemic plakortolide I (2). ${ }^{13}$ Ten years later, Vatèle ${ }^{14}$ described an asymmetric synthesis of the (-)-plakortolide I (2) and (+)-plakortolide E (1).

In our retrosynthetic approach, we envisioned a latestage endoperoxide formation by a tandem Mukaiyama hydroperoxidation/oxa-Michael addition sequence to access either of the two natural products. Installation of the side chain by allylic substitution would simplify both epimeric natural products $\mathbf{1}$ and $\mathbf{2}$ retrosynthetically to allyl acetate $\mathbf{4}$ which we traced back to our starting material 5. Herein, we report a seven-step synthesis of enantiopure (+)-plakortolide E (1) and (-)-plakortolide I (2) from commercially available monoterpenoid $(R)$ linalool (5) (Scheme 1).

Scheme 1. Retrosynthetic Analysis of (+)-Plakortolide E and (-)-Plakortolide I

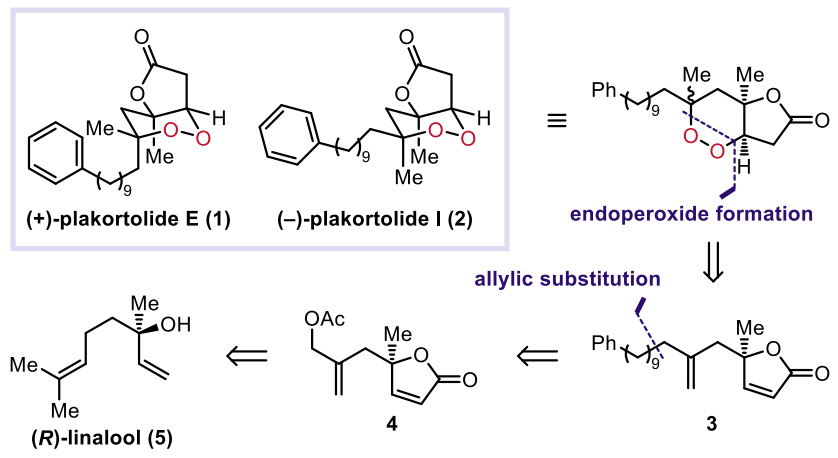

The synthesis commenced with the chemoselective vanadium-catalyzed epoxidation of the terminal double bond providing the corresponding epoxide as an inconsequential mixture of both diastereomers ( $\mathrm{dr} 3: 2)$ in $74 \%$ yield (see Supporting Information). ${ }^{15}$ Opening of the epoxides with potassium cyanide under acidic conditions afforded both diastereomers of nitrile $6(80 \%$ yield). Hydrolysis under basic conditions followed by acidic lactonization in an aqueous medium provided the corresponding butyrolactone in $80 \%$ yield after isolation (see Supporting Information). In a subsequent step, 
eliminiation of the hydroxyl group was achieved by treatment with acetic anhydride in the presence of triethylamine to give the desired butenolide 7 in $81 \%$ yield. Gratifyingly, we found that the hydrolysis and the lactonization step could be combined in a tandem process mediated by $p \mathrm{TsOH} \cdot \mathrm{H}_{2} \mathrm{O}$ in DMF. Upon treatment with acetic anhydride and triethylamine, elimination of the hydroxyl group could be achieved, thus allowing the synthesis of butenolide 7 from nitrile 6 in a one-pot procedure with an overall yield of $69 \%$. Butenolide 7 was subjected to a one-pot ozonolysis/ $\alpha$ methylenation $^{16}$ (68\% yield). The resulting enal was reduced by pyridine zinc borohydride in ethyl acetate to directly furnish allyl acetate $4 .^{17}$

\section{Scheme 2. Synthesis of Allyl acetate 4}

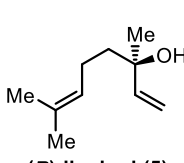

R)-linalool (5)

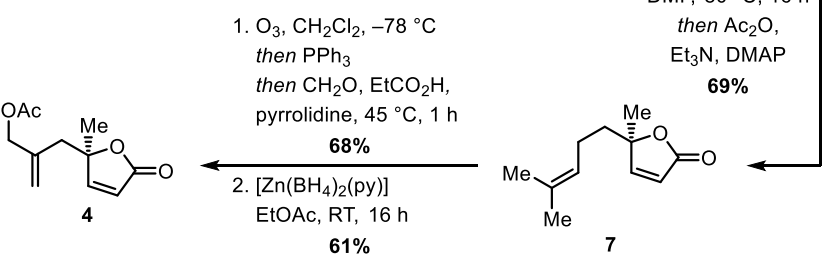

With a precursor for the allylic substitution in hand, we investigated the installation of the side chain. Initial attempts to couple both fragments by cupratemediated allylic substitution failed. We recognized a chemoselectivity challenge imposed by the substrate, as it is known that many transition metals catalyze both allylic substitutions and conjugate additions. ${ }^{18}$ To shut down the competing pathway, we investigsted alternative processes. ${ }^{19}$ Although palladium-catalyzed conjugate additions have been reported in recent years, ${ }^{20}$ we anticipated that selectivity for the allylic substitution is achievable. However, typical nucleophiles for TsujiTrost-type reactions are either heteroatoms or stabilized carbanions, e. g. enolates, deprotonated sulfones and alkynes. ${ }^{19,21}$ In contrast, the use of organomagnesium compounds is plagued by $\beta$-hydride elimination of the organometallic reagent or umpolung ${ }^{22}$ of the $\pi$-allyl palladium complex into a nucleophile. When we examined the palladium-catalyzed allylic substitution with diethylzinc, we observed deoxygenation, presumably via $\beta$-hydride elimination and subsequent reductive elimination. ${ }^{23}$ Although there have been reports by Maulide and coworkers to suppress those competing pathways and promote reductive elimination, their studies were limited to diethylzinc and required non-commercially available ligands. ${ }^{24}$ Recently Li and coworkers described a method for the palladium-catalyzed C-allylation of deprotonated hydrazones as surrogates for nonstabilized carbon nucleophiles. ${ }^{25}$ When allyl acetate $\mathbf{4}$ was treated with hydrazone $\mathbf{8}$, the formation of coupling product 3 was observed, albeit in only $16 \%$ yield (Scheme 3). Next, we proceeded to investigate approaches involving cobalt, nickel and iron catalysis as for these metals reactions with non-stabilized nucleophiles are described. ${ }^{26}$ Unfortunately, attempts using cobalt and nickel suffered from either no conversion or decomposition. Recently, Jacobi von Wangelin and coworkers showed that inexpensive $\mathrm{Fe}(\mathrm{OAc})_{2}$ is an efficient catalyst for the allylic substitution with alkylmagnesium halides under mild conditions. ${ }^{26 e}$ Their protocol effectively inhibits competing $\beta$-hydride elimination without the need of stabilizing ligands or solvents. Initial treatment of allyl acetate $\mathbf{4}$ with alkylmagnesium bromide 9 in the presence of catalytic amounts of $\mathrm{Fe}(\mathrm{OAc})_{2}$ in $\mathrm{Et}_{2} \mathrm{O}$ gave no conversion, presumably due to limited solubility. Interstingly, we found that addition of $\mathrm{LiCl}$ in THF afforded the desired product 3 in $66 \%$ yield (Scheme 3). ${ }^{26 e}$

\section{Scheme 3. Chemoselective Allylic Substitution of 4}

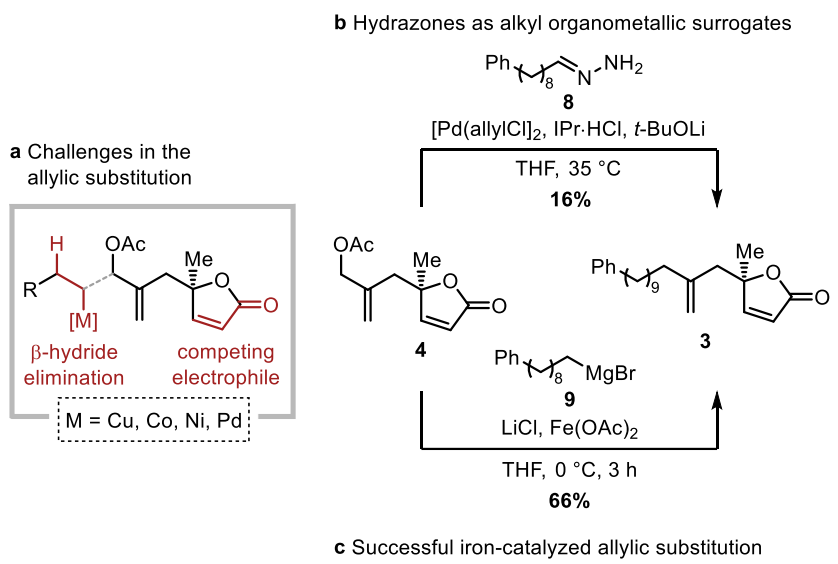

Having assembled the carbon skeleton, we addressed the remaining challenge of introducing the endoperoxide. Inspired by the application of cobalt catalyzed hydrofunctionalizations with oxygen in total synthesis, ${ }^{27}$ we anticipated a chemo- and regioselective hydroperoxidation of olefin $\mathbf{3}$ followed by an oxa-Michael addition in a tandem process to furnish both natural products 1 and 2. Unfortunately, Mukaiyama-Isayama hydroperoxidation of $\mathbf{3}$ with $\mathrm{Et}_{3} \mathrm{SiH}$ and $\mathrm{Co}(\text { thd })_{2}$ in vigorously oxygen saturated 1,2-DCE at ambient temperature resulted in no conversion even at prolonged reaction time or elevated temperature. ${ }^{14}$ However, addition of protic solvents such as $i$-PrOH facilitated the conversion. Under these conditions, the direct formation of endoperoxides $\mathbf{1}$ and $\mathbf{2}$ was observed, but was accompanied by decomposition of the products resulting in low isolated 
yields. Although decomposition reactions could be suppressed at $0{ }^{\circ} \mathrm{C}$, the oxa-Michael addition was slowed down and the intermediate was partially trapped as the corresponding silyl peroxide. This drawback was circumvented by in situ desilylation with TBAF in the presence of TFE (2,2,2-trifluoroethanol) to buffer the enolate resulting from the oxa-Michael reaction, thereby avoiding potential Weitz-Scheffer-type epoxidation. ${ }^{14}$ This tandem endoperoxide formation afforded (-)plakortolide I (2) in $42 \%$ yield, along with its C6-epimer (+)-plakortolide E (1) in 35\% yield. Single crystals of 1 were grown and analyzed by $\mathrm{X}$-ray analysis, thereby confirming the structure and absolute configuration of 1 and indirectly of $\mathbf{2}$ (Scheme 4).

Scheme 4. Tandem Endoperoxide Formation for the Synthesis of (+)-Plakortolide E and (-)-Plakortolide I (Thermal Ellipsoids at 50\% Probability; Disorder Was Obmitted for Clarity)
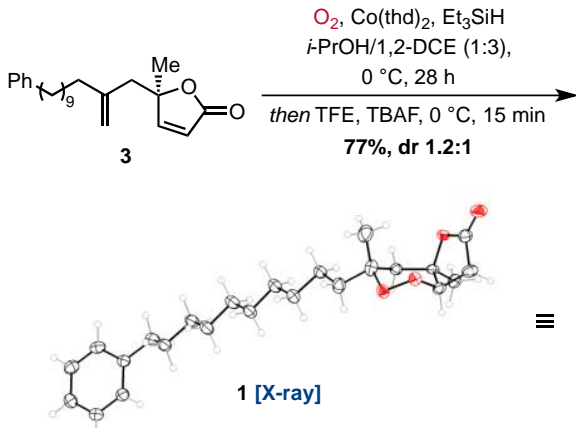

$\equiv$

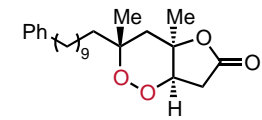

(+)-plakortolide E (1)
To illustrate the efficiency of our synthesis, we applied a color-coded flowchart representation that was recently developed by our group (Figure 1). ${ }^{6 c}$ More than half of the transformations are strategic bond forming reactions that utilize all the functional groups given by the chiral terpene starting material $\mathbf{5}$. Two functional group interconversions were combined with constructive bond formations in one-pot procedures to enhance the pot economy of the synthesis.
C-C-bond formation/cleavage (strategic)

I C-Het-bond formation/cleavage, redox reaction (strategic)

functional group interconversion, isomerization

it non-strategic redox reactions

protecting group manipulations

one-pot procedure

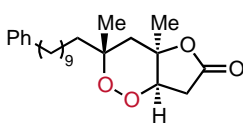

(+)-plakortolide E (1)

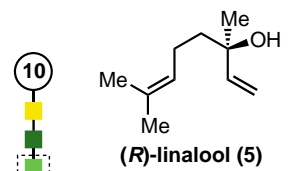

$17 \%$ ( 5 steps)
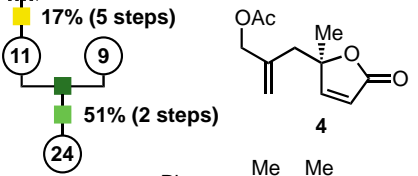

7 steps LLS OY: $9 \%$

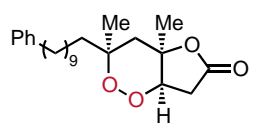

(-)-plakortolide I (2)

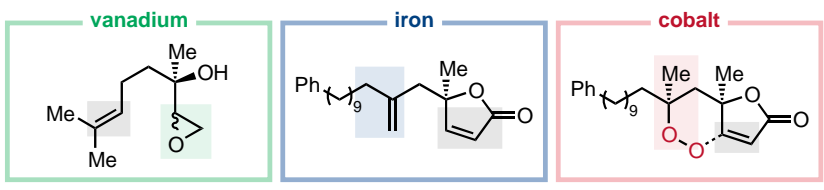

Figure 1. Flowchart representation of the synthesis of (+)plakortolide E (1) and (-)-plakortolide I (2).

In conclusion we have developed a concise synthesis of enantiopure (+)-plakortolide $E$ (1) and (-)plakortolide I (2) from commercially available (R)linalool (5). By using an $\mathrm{Fe}(\mathrm{OAc})_{2}$ catalyst, a chemoselective installation of the alkyl side chain was achieved in good yield. This work demonstrates that a straightforward and protecting-group-free synthesis of endoperoxide natural products can be fueled by chemoselective transformations with earth-abundant transition metal catalysts.

\section{ASSOCIATED CONTENT}

\section{Supporting Information.}

The Supporting Information is available free of charge on the ACS Publications website.

X-ray crystallographic data for $\mathbf{1}$ (CIF)

Experimental procedures and spectroscopic data (PDF)

\section{AUTHOR INFORMATION}

Corresponding Author

*E-mail: mathias.christmann@fu-berlin.de

ORCID

Mathias Christmann: 0000-0001-9313-2392

Notes

The authors declare no competing financial interest.

\section{ACKNOWLEDGMENT}


We thank Luise Schefzig for preparative support and Merlin Kleoff (both Freie Universität Berlin) for helpful discussions.

\section{REFERENCES}

(1) Hendrickson, J. B. Systematic Synthesis Design. IV. Numerical codification of construction reactions. J. Am. Chem. Soc. 1975, 97, 5784-5800.

(2) (a) Trost, B. M. The atom economy - a search for synthetic efficiency. Science 1991, 254, 1471-1477. (b) Trost, B. M. Atom Economy - A Challenge for Organic Synthesis: Homogeneous Catalysis Leads the Way. Angew. Chem. Int. Ed. 1995, 34, 259-281.

(3) Burns, N. Z.; Baran, P. S.; Hoffmann, R. W. Redox economy in organic synthesis. Angew. Chem. Int. Ed. 2009, 48, 2854-2867.

(4) (a) Wender, P. A.; Verma, V. A.; Paxton, T. J.; Pillow, T. H. Function-Oriented Synthesis, Step Economy, and Drug Design. Acc. Chem. Res. 2008, 41, 40-49. (b) Wender, P. A.; Miller, B. L. Synthesis at the molecular frontier. Nature 2009, 460, 197-201.

(5) (a) Hayashi, Y. Pot economy and one-pot synthesis. Chem. Sci. 2016, 7, 866-880. (b) Hayashi, Y. Time and Pot Economy in Total Synthesis. Acc. Chem. Res. 2021, 54, 1385-1398.

(6) (a) Newhouse, T.; Baran, P. S.; Hoffmann, R. W. The economies of synthesis. Chem. Soc. Rev. 2009, 38, 3010-3021. (b) Gaich, T.; Baran, P. S. Aiming for the Ideal Synthesis. J. Org. Chem. 2010, 75, 4657-4673. (c) Schwan, J.; Christmann, M. Enabling strategies for step efficient syntheses. Chem. Soc. Rev. 2018, 47, 7985-7995.

(7) (a) Zweig, J. E.; Kim, D. K.; Newhouse, T. R. Methods Utilizing First-Row Transition Metals in Natural Product Total Synthesis. Chem. Rev. 2017, 117, 11680-11752. (b) Beaumier, E. P.; Pearce, A. J.; See, X. Y.; Tonks, I. A. Modern applications of low-valent early transition metals in synthesis and catalysis. Nat. Chem. Rev. 2019, 3, 15-34. (c) Bullock, R. M.; Chen, J. G.; Gagliardi, L.; Chirik, P. J.; Farha, O. K.; Hendon, C. H.; Jones, C. W.; Keith, J. A.; Klosin, J.; Minteer, S. D.; Morris, R. H.; Radosevich, A. T.; Rauchfuss, T. B.; Strotman, N. A.; Vojvodic, A.; Ward, T. R.; Yang, J. Y.; Surendranath, Y. Using nature's blueprint to expand catalysis with Earth-abundant metals. Science 2020, 369, eabc3183.

(8) Bu, M.; Yang, B. B.; Hu, L. Natural Endoperoxides as Drug Lead Compounds. Curr. Med. Chem. 2016, 23, 383-405.

(9) (a) Dembitsky, V. M.; Gloriozova, T. M.; Poroikov, V. V. Natural Peroxy Anticancer Agents. Mini Rev. Med. Chem. 2007, 7, 571-589. (b) Dembitsky, V. M. Bioactive peroxides as potential therapeutic agents. Eur. J. Med. Chem. 2008, 43, 223-251.

(10) (a) Tu, Y. Artemisinin-A Gift from Traditional Chinese Medicine to the World (Nobel Lecture). Angew. Chem. Int. Ed. 2016, 55, 10210-10226. (b) Wang, J.; Xu, C.; Wong, Y. K.; Li, Y.; Liao, F.; Jiang, T.; Tu, Y. Artemisinin, the Magic Drug Discovered from Traditional Chinese Medicine. Engineering. 2019, 5, 32-39.

(11) Qureshi, A.; Salvà, J.; Harper, M.; Faulkner, D. J. New Cyclic Peroxides from the Philippine Sponge Plakinastrella sp. J. Nat. Prod. 1998, 61, 1539-1542.

(12) (a) Rudi, A.; Afanii, R.; Gravalos, L. G.; Aknin, M.; Gaydou, E.; Vacelet, J.; Kashman, Y. Three New Cyclic Peroxides from the Marine Sponge Plakortisaff simplex. J. Nat. Prod. 2003, 66, 682-685. (b) Correction of the initially assigned structure to (+)-plakortolide $\mathrm{E}$ : .Plakortolide Stereochemistry Revisited: Yong, K. W. L.; Barnych, B.; De Voss. J. J.; Vatèle, J.-M.; Garson, M. J. The Checkered History of Plakortolides E and I. J. Nat. Prod. 2012, 75, 1792-1797.

(13) Jung, M.; Ham, J.; Song, J. First Total Synthesis of Natural 6Epiplakortolide E. Org. Lett. 2002, 16, 2763-2765.

(14) Barnych, B.; Vatèle, J.-M. Total Synthesis of seco-Plakortolide $\mathrm{E}$ and (-)-ent-Plakortolide I: Absolute Configurational Revision of Natural Plakortolide I. Org. Lett. 2012, 14, 564-567.
(15) Langhanki, J.; Rudolph, K.; Erkel, G.; Opatz, T. Total synthesis and biological evaluation of the natural product (-)-cyclonerodiol, a new inhibitor of IL-4 signaling. Org. Biomol. Chem. 2014, 12, 97079715.

(16) Benohoud, M.; Erkkilä, A.; Pihko, P. M. ORGANOCATALYTIC METHYLENATION OF ALDEHYDES: PREPARATION OF 3,7-DIMETHYL2-METHYLENE-6-OCTENAL. Org. Synth. 2010, 87, 201-208.

(17) Zeynizadeh, B.; Setamdideh, D.; Faraji, F. Reductive Acetylation of Carbonyl Compounds to Acetates with Pyridine Zinc Borohydride. Bull. Korean Chem. Soc. 2008, 29, 76-80.

(18) (a) Hayashi, T.; Yamasaki, K. Rhodium-Catalyzed Asymmetric 1,4-Addition and Its Related Asymmetric Reactions. Chem. Rev. 2003, 103, 2829-2844. (b) Alexakis, A.; Bäckvall, J. E.; Krause, N.; Pàmies, O.; Diéguez, M. Enantioselective Copper-Catalyzed Conjugate Addition and Allylic Substitution Reactions. Chem. Rev. 2008, 108, 27962823. (c) Bauer, I.; Knölker, H.-J. Iron Catalysis in Organic Synthesis. Chem. Rev. 2015, 115, 3170-3387. (d) Butt, N. A.; Zhang, W. Transition metal-catalyzed allylic substitution reactions with unactivated allylic substrates. Chem. Soc. Rev. 2015, 44, 7929-7967.

(19) (a) Trost, B. M.; Crawley, M. L. Asymmetric Transition-MetalCatalyzed Allylic Alkylations: Applications in Total Synthesis. Chem. Rev. 2003, 103, 2921-2944. (b) Lu, Z.; Ma, S. Metal-Catalyzed Enantioselective Allylation in Asymmetric Synthesis. Angew. Chem. Int. Ed. 2007, 47, 258-297.

(20) (a) Cacchi, S.; Misiti, D.; Palmieri, G. The palladium-catalysed conjugate addition type reaction of arylmercury compounds with $\alpha, \beta$-unsaturated ketones in a two-phase system. Tetrahedron 1981, 37, 2941-2946. (b) Nishikata, T.; Yamamoto, Y.; Miyaura, N. Conjugate Addition of Aryl Boronic Acids to Enones Catalyzed by Cationic Palladium(II)-Phosphane Complexes. Angew. Chem. Int. Ed. 2003, 42, 2768-2770. (c) Gutnov, A. Palladium-Catalyzed Asymmetric Conjugate Addition of Aryl-Metal Species. Eur. J. Org. Chem. 2008, 45474554. (d) Lin, S.; Lu, X. Cationic Pd(II)/Bipyridine-Catalyzed Conjugate Addition of Arylboronic Acids to $\beta, \beta$-Disubstituted Enones: Construction of Quaternary Carbon Centers. Org. Lett. 2010, 12, 2536-2539. (e) Gottumukkala, A. L.; Matcha, K.; Lutz, M.; de Vries, J. G., Minnaard, A. J. Palladium-Catalyzed Asymmetric Quaternary Stereocenter Formation. Chem. Eur. J. 2012, 18, 6907-6914. (f) Chen, W.; Chen, H.; Xiao, F.; Deng, G.-J. Palladium-catalyzed conjugate addition of arylsulfonyl hydrazides to $\alpha, \beta$-unsaturated ketones. Org. Biomol. Chem. 2013, 11, 4295-4298.

(21) (a) Weaver, J. D.; Tunge, J. A. Decarboxylative Allylation using Sulfones as Surrogates of Alkanes. Org. Lett. 2008, 10, 4657-4660. (b) Trost, B. M.; Zhang, T.; Sieber, J. D. Catalytic asymmetric allylic alkylation employing heteroatom nucleophiles: a powerful method for C-X bond formation. Chem. Sci. 2010, 1, 427-440. (c) Li, Y.-X.; Xuan, Q.-Q., Liu, L.; Wang, D.; Chen, Y.-J.; Li, C.-J. A Pd(0)-Catalyzed Direct Dehydrative Coupling of Terminal Alkynes with Allylic Alcohols To Acces 1,4-Enynes. J. Am. Chem. Soc. 2013, 135, 12536-12539. (d) Akkarasamiyo, S.; Sawadjoon, S.; Orthaber, A.; Samec, J. S. M. TsujiTrost Reaction of Non-Derivatized Allylic Alcohols. Chem. Eur. J. 2018, 24, 3488-3498.

(22) (a) Tamaru, Y.; Tanaka, A., Yasui, K.; Goto, S.; Tanaka, S. Highly Stereoselective Allylation of Benzaldehyde: Generation of a Stereochemically Defined Allylzinc Species from a $\pi$-Allylpalladium Intermediate and Diethylzinc. Angew. Chem. Int. Ed. 1995, 34, 787-789. (b) Howell, G. P.; Minnaard, A. J.; Feringa, B. L. Asymmetric allylation of aryl aldehydes: studies on the scope and mechanism of the palladium catalyzed diethylzinc mediated umpolung using phosphoramidite ligands. Org. Biomol. Chem. 2006, 4, 1278-1283. (c) Spielmann, K.; Niel, G.; de Figueiredo, R. M.; Campagne, J.-M. Catalytic nucleophilic 'umpoled' $\pi$-allyl reagents. Chem. Soc. Rev. 2018, 47, 1159-1173.

(23) (a) Yuan, K.; Scott, W. J. On the mechanism of the reduction of primary halides with Grignard reagents in the presence of (dppf) $\mathrm{PdCl} 2$ or (dppf)Pd(0). J. Org. Chem. 1990, 55, 6188-6194. (b) Fukuda, J.-i.; Nogi, K.; Yorimitsu, H. Cobalt-Catalyzed Reduction of 
Aryl Sulfones to Arenes by Means of Alkylmagnesium Reagents. Asian J. Org. Chem. 2018, 7, 2049-2052.

(24) Misale, A.; Niyomchon, S.; Luparia, M.; Maulide, N. Asymmetric Palladium-Catalyzed Allylic Alkylation Using Dialkylzinc Reagents: A Remarkable Ligand Effect. Angew. Chem. Int. Ed. 2014 53, 70687073.

(25) Zhu, D.; Lv, L.; Li, C.-C.; Ung, S.; Gaom, J.; Li, C.-J. Umpolung of Carbonyl Groups as Alkyl Organometallic Reagent Surrogates for Palladium-Catalyzed Allylic Alkylation. Angew. Chem. Int. Ed. 2018, $57,16520-16524$.

(26) (a) Qian, X.; Auffrant, A.; Felouat, A.; Gosmini, C. CobaltCatalyzed Reductive Allylation of Alkyl Halides with Allylic Acetates or Carbonates. Angew. Chem. Int. Ed. 2011, 50, 10402-10405. (b) Yonova, I. M.; Johnson, A. G.; Osborne, C. A.; Moore, C. E.; Morrissette, N. S.; Jarvo, E. R. Stereospecific Nickel-Catalyzed Cross-Coupling Reactions of Alkyl Grignard Reagents and Identification of Selective AntiBreast-Cancer Agents. Angew. Chem. Int. Ed. 2014, 53, 2422-2427. (c) Yang, B.; Wang, Z.-X. Nickel-Catalyzed Alkylation or Reduction of Allylic Alcohols with Alkyl Grignard Reagents. J. Org. Chem. 2020, 85, 4772-4784. (d) Cahiez, G.; Avedissian, H. Highly Stereo- and Chemoselective Iron-Catalyzed Alkenylation of Organomagnesium
Compounds. Synthesis 1998, 1199-1205. (e) Bernauer, J.; Wu, G.; Jacobi von Wangelin, A. Iron-catalysed allylation-hydrogenation sequence as masked alkyl-alkyl cross-couplings. RSC Adv. 2019, 9, 31217-31223.

(27) (a) Mukaiyama, T.; Isayama, S.; Inoki, S.; Kato, K.; Yamada, T.; Takai, T. Oxidation-Reduction Hydration of Olefins with Molecular Oxygen and 2-Propanol Catalyzed by Bis(acetylacetonato)cobalt(II). Chem. Lett. 1989, 18, 449-452. (b) Isayama, S.; Mukaiyama, T. Novel Method for the Preparation of Triethylsilyl Peroxides from Olefins by the Reaction with Molecular Oxygen and Triethylsilane Catalyzed by Bis(1,3-diketonato)cobalt(II). Chem. Lett. 1989, 18, 573-576. (c) Isayama, S. An Efficient Method for the Direct Peroxygenation of Various Olefinic Compounds with Molecular Oxygen and Triethylsilane Catalyzed by a Cobalt(II) Complex. Bull. Chem. Soc. Jpn. 1990, 63, 1305-1310. (d) Crossley, S. W. M.; Obradors, C.; Martinez, R. M.; Shenvi, R. A. Mn-, Fe-, and Co-Catalyzed Radical Hydrofunctionalizations of Olefines. Chem. Rev. 2016, 116, 8912-9000.

Authors are required to submit a graphic entry for the Table of Contents (TOC) that, in conjunction with the manuscript title, should give the reader a representative idea of one of the following: A key structure, reaction, equation, concept, or theorem, etc., that is discussed in the manuscript. Consult the journal's Instructions for Authors for TOC graphic specifications.

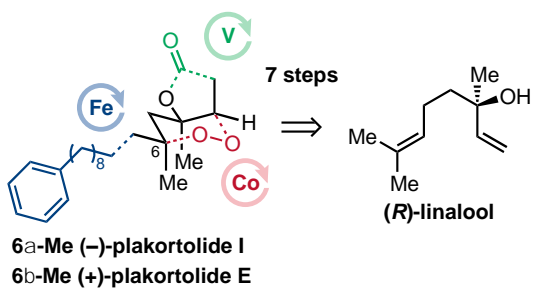




\section{Synthesis of Plakortolides E and I Enabled by Base Metal Catalysis}

Stefan Leisering, Alexandros Mavroskoufis, Patrick Voßnacker, Reinhold Zimmer, Mathias Christmann*

Institut für Chemie und Biochemie, Freie Universität Berlin, Takustraße 3, 14195 Berlin, Germany

\section{Supporting Information}

\section{Table of Content}

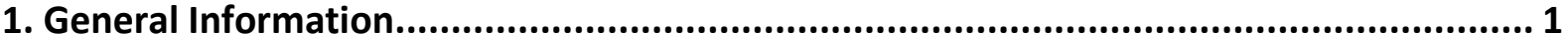

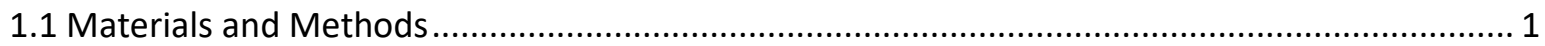

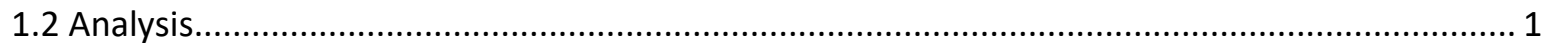

2. Experimental Procedures and Analytical Data....................................................... 2

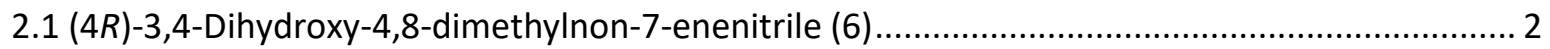

2.2 (5R)-4-Hydroxy-5-methyl-5-(4-methylpent-3-ene-1-yl)oxolan-2-one (SI-2) ............................ 2

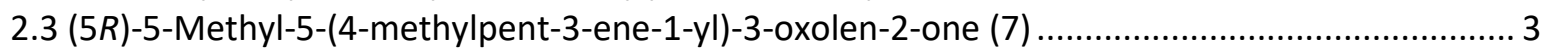

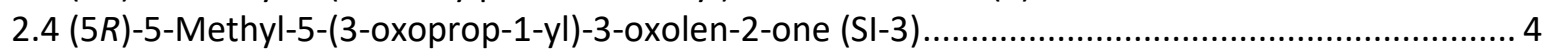

2.5 (5R)-5-Methyl-5-(2-methylene-3-oxoprop-1-yl)-3-oxolen-2-one (SI-4) .................................... 5

2.6 (5R)-5-Methyl-5-(3-(acetyloxy)-2-methyleneprop-1-yl)-3-oxolen-2-one (4) ................................ 5

2.7 (5R)-5-Methyl-5-(12-phenyl-2-methylenedodec-1-yl)-3-oxolen-2-one (3).................................. 6

$2.8(3 R, 4 \mathrm{a} R, 7 \mathrm{a} R)$-3,4a-dimethyl-6-oxo-3-(10-phenyldec-1-yl)oxolano[3,2-c]-1,2-dioxane (1) and

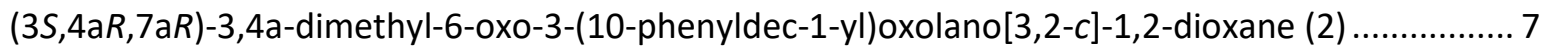

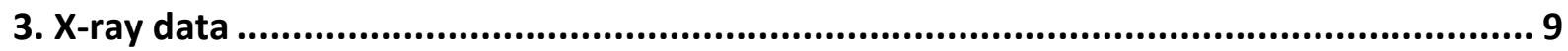

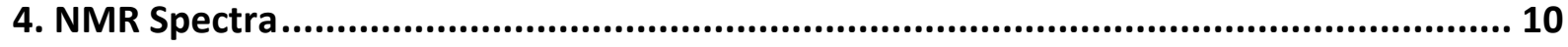

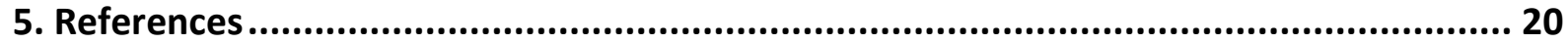




\section{General Information}

\subsection{Materials and Methods}

Reactions with air or moisture sensitive substances were carried out under an argon atmosphere using standard Schlenk technique. Ambient or room temperature (RT) refers to $18-23^{\circ} \mathrm{C}$.

Unless otherwise noted, all staring materials and reagents were purchased from commercial distributors and used without further purification. Anhydrous dichloromethane, tetrahydrofuran and toluene were provided by purification with a MBraun SPS- 800 solvent system (BRAUN) using solvents of HPLC grade purchased from FISCHER Scientific and ROTH. Anhydrous N,N-dimethylformamide and 1,2-Dichloroethane $(99.8+\%)$ were purchased from ACROS Organics. HPLC-grade 2-propanol was purchased from VWR. Triethylamine was distilled from calcium hydride and stored under argon over $\mathrm{KOH}$. Solvents for extraction, crystallization and flash column chromatography were purchased in technical grade and distilled under reduced pressure prior to use.

Column chromatography was performed on silica $60 \mathrm{M}$ (0.040-0.063 mm, 230-400 mesh, MACHEREYNAGEL).

Medium pressure liquid chromatography (MPLC) was performed with a TELEDYNE ISCO Combi-Flash Rf200 using prepacked silica columns and cartridges from TELDYNE. UV response was monitored at $254 \mathrm{~nm}$ and $280 \mathrm{~nm}$. As eluents, cyclohexane (99.5+\% quality) and EtOAc (HPLC grade) were used.

The following compounds were prepared according to the literature: SI-1, ${ }^{1}$ pyridine zinc borohydride, ${ }^{2}$ 9phenylnonanal, ${ }^{3}$ (9-bromononyl)benzene. ${ }^{4}$

\subsection{Analysis}

Reaction monitoring: Reactions were monitored by thin layer chromatography (TLC). TLC-analysis was performed on silica gel coated aluminum plates ALUGRAM ${ }^{\oplus}$ Xtra SIL G/UV ${ }_{254}$ purchased from MACHEREYNAGEL. Products were visualized by UV light at $254 \mathrm{~nm}$ and by using staining reagents (based on $\mathrm{KMnO}_{4}$ and anisaldeyhde).

NMR spectroscopy: ${ }^{1} \mathrm{H}$ NMR and ${ }^{13} \mathrm{C}$ NMR spectral data were recorded on JEOL (ECX 400, ECP 500) and BRUKER (AVANCE III 500, AVANCE III 700) spectrometer in the reported deuterated solvents. The chemical shifts $(\delta)$ are listed in parts per million $(\mathrm{ppm})$ and are reported relative to the corresponding residual nondeuterated solvent signal $\left(\mathrm{CDCl}_{3}: \delta_{H}=7.26 \mathrm{ppm}, \delta_{c}=77.16 \mathrm{ppm}\right)$. Integrals are in accordance with assignments; coupling constants $(J)$ are given in $\mathrm{Hz}$. Multiplicity is indicated as follows: $\mathrm{s}$ (singlet), d (doublet), $\mathrm{t}$ (triplet), q (quartet), $\mathrm{br}=$ broad and combinations thereof. In the case where no multiplicity could be identified, the chemical shift range of the signal is given as $\mathrm{m}$ (multiplet). ${ }^{13} \mathrm{C} N M R$ spectra are ${ }^{1} \mathrm{H}$ broadband decoupled. For detailed peak assignments 2D spectra were measured (COSY, HMQC, HMBC).

High resolution mass spectrometry: High resolution mass spectra (HRMS) were measured with an AGILENT $6210 \mathrm{ESI}-\mathrm{TOF}(10 \mu \mathrm{L} / \mathrm{min}, 1.0 \mathrm{bar}, 4 \mathrm{kV})$ instrument.

Optical rotation: Optical rotation values were measured with a JACSO P-2000 polarimeter at $589 \mathrm{~nm}$ using $100 \mathrm{~mm}$ cells and the indicated solvent and concentration $(\mathrm{g} / 100 \mathrm{~mL})$ at the given temperatures.

Melting points: Melting points were determined by a digital melting point apparatus (Büchi B-545) and are uncorrected.

X-ray: X-ray diffraction data was collected on a BRUKER D8 Venture CMOS area detector (Photon 100) diffractometer with $\mathrm{Cu}_{\mathrm{k} \alpha}$ radiation. Single crystals were coated with perfluoroether oil and mounted on a $0.2 \mathrm{~mm}$ Micromount. The structures were solved with the ShelXT ${ }^{5}$ structure solution program using intrinsic phasing and refined with the ShelXL ${ }^{6}$ refinement package using least squares on weighted $\mathrm{F} 2$ values for all reflections using OLEX $2 .^{7}$ 


\section{Experimental Procedures and Analytical Data}

\section{1 (4R)-3,4-Dihydroxy-4,8-dimethylnon-7-enenitrile (6)}

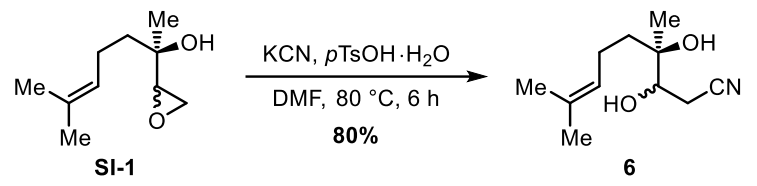

To a flame-dried Schlenk flask containing a suspension of potassium cyanide $(5.02 \mathrm{~g}, 77.0 \mathrm{mmol}$, 2.5 equiv) and para-toluenesulfonic acid monohydrate $(7.04 \mathrm{~g}, 37.0 \mathrm{mmol}, 1.2$ equiv) in anhydrous $\mathrm{N}, \mathrm{N}$ dimethylformamide $(50 \mathrm{~mL})$ under an argon atmosphere was added a solution of diastereomeric ( $\mathrm{dr}(2 \mathrm{~S}$, $3 R):(2 R, 3 R))=3: 2)$ epoxide SI-1 $(5.25 \mathrm{~g}, 30.8 \mathrm{mmol}, 1.0$ equiv) in anhydrous $\mathrm{N}, \mathrm{N}$-dimethylformamide $(10 \mathrm{~mL})$ at $40{ }^{\circ} \mathrm{C}$. The resulting mixture was heated to $80^{\circ} \mathrm{C}$ and stirred for $6 \mathrm{~h}$. TLC analysis indicated complete consumption of the starting material. After cooling to $0{ }^{\circ} \mathrm{C}$, the reaction was quenched by the addition of saturated aqueous $\mathrm{NaHCO}_{3}(50 \mathrm{~mL})$ and $\mathrm{H}_{2} \mathrm{O}(50 \mathrm{~mL})$. The mixture was extracted with EtOAc $(3$ $\times 100 \mathrm{~mL})$. The combined organic extracts were washed with brine $(100 \mathrm{~mL})$, dried over anhydrous $\mathrm{Na}_{2} \mathrm{SO}_{4}$, filtered and concentrated under reduced pressure. The crude product was purified by column chromatography ( $\mathrm{SiO}_{2}$, pentane/EtOAc, $4: 1$ to $\left.2: 1\right)$ to afford nitrile $6(4.88 \mathrm{~g}, 24.7 \mathrm{mmol}, 80 \%)$ as a colorless oil.

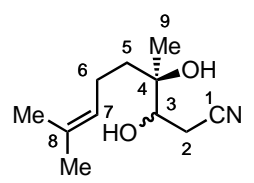

${ }^{1} \mathrm{H}$ NMR $\left(700 \mathrm{MHz}, \mathrm{CDCl}_{3}\right): \delta=1.14\left(\mathrm{~s}, 1.2 \mathrm{H}, \mathrm{H}-9_{R}\right), 1.21\left(\mathrm{~s}, 1.8 \mathrm{H}, \mathrm{H}-9_{\mathrm{s}}\right), 1.35-1.44\left(\mathrm{~m}, 0.6 \mathrm{H}, \mathrm{H}-5_{\mathrm{s}}\right), 1.51-$ $1.59\left(\mathrm{~m}, 1.4 \mathrm{H}, \mathrm{H}-5_{\mathrm{s}}, \mathrm{H}-5_{\mathrm{R}}\right), 1.62(\mathrm{~s}, 3 \mathrm{H}, \mathrm{Me}), 1.68(\mathrm{~s}, 3 \mathrm{H}, \mathrm{Me}), 1.99-2.15(\mathrm{~m}, 2 \mathrm{H}, \mathrm{H}-6), 2.52-2.65(\mathrm{~m}, 1 \mathrm{H}$, $\mathrm{H}-2), 3.73-3.83(\mathrm{~m}, 1 \mathrm{H}, \mathrm{H}-3), 5.06-5.12(\mathrm{~m}, 1 \mathrm{H}, \mathrm{H}-7) \mathrm{ppm}$.

${ }^{13} \mathrm{C}$ NMR $(176 \mathrm{MHz}, \mathrm{CDCl}): \delta=17.81\left(\mathrm{Me}_{R}\right), 17.83\left(\mathrm{Me}_{s}\right), 21.1\left(\mathrm{C}-2_{s}\right), 21.2\left(\mathrm{C}-2_{R}\right), 21.7\left(\mathrm{C}-9_{R}\right), 22.1\left(\mathrm{C}-6_{s}\right)$, $22.3\left(\mathrm{C}-6_{R}\right), 22.6\left(\mathrm{C}-9_{s}\right), 25.8(\mathrm{Me}), 37.4\left(\mathrm{C}-5_{s}\right), 38.5\left(\mathrm{C}-5_{R}\right), 72.7\left(\mathrm{C}-3_{R}\right), 73.3\left(\mathrm{C}-3_{s}\right), 74.18\left(\mathrm{C}-4_{R}\right), 74.20$ (C4s), $119.0\left(\mathrm{C}-1_{R}\right), 119.2\left(\mathrm{C}-1_{S}\right), 123.79\left(\mathrm{C}-7_{S}\right), 123.81\left(\mathrm{C}-7_{R}\right), 132.6\left(\mathrm{C}-8_{R}\right), 132.8$ (C-8s) ppm.

HRMS (ESI, pos.): $\mathrm{m} / z$ calcd for $\mathrm{C}_{11} \mathrm{H}_{19} \mathrm{NO}_{2} \mathrm{Na}^{+}\left[\mathrm{M}+\mathrm{Na}^{+}\right]$: 220.1308, found 220.1328 .

\section{2 (5R)-4-Hydroxy-5-methyl-5-(4-methylpent-3-ene-1-yl)oxolan-2-one (SI-2)}

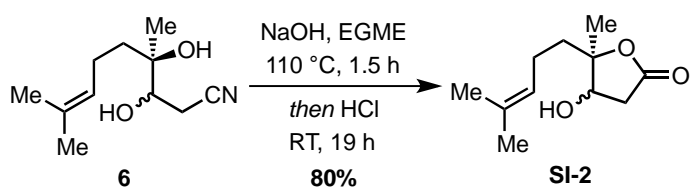

A solution of nitrile $6(4.80 \mathrm{~g}, 24.3 \mathrm{mmol}, 1.00$ equiv) in ethylene glycol monomethyl ether $(25 \mathrm{~mL})$ and aqueous $2 \mathrm{M} \mathrm{NaOH}\left(66 \mathrm{~mL}\right.$ ) was heated to $110^{\circ} \mathrm{C}$ and stirred for $1.5 \mathrm{~h}$. After cooling to $0{ }^{\circ} \mathrm{C}$, aqueous $2 \mathrm{M}$ $\mathrm{HCl}(80 \mathrm{~mL})$ was added until a $\mathrm{pH}$ of 2 was reached. The cooling bath was removed and the reaction mixture was stirred for a further $19 \mathrm{~h}$. The solution was extracted with EtOAc $(3 \times 100 \mathrm{~mL})$ and the combined organic extracts were washed with brine $(150 \mathrm{~mL})$, dried over anhydrous $\mathrm{Na}_{2} \mathrm{SO}_{4}$, filtered and concentrated under reduced pressure. The crude product was purified by column chromatography $\left(\mathrm{SiO}_{2}\right.$, pentane/EtOAc, 3:1 to 2:1) to afford lactone SI-2 $(3.84 \mathrm{~g}, 19.3 \mathrm{mmol}, 80 \%)$ as a colorless oil.

Both diastereomers could by separated by column chromatography to obtain analytically pure samples which were used for the characterization.

trans-Lactone SI-2 (major diastereomer) 


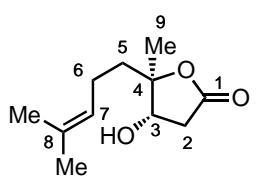

$[\alpha]_{D}^{22}=+2.6\left(c=1.00, \mathrm{CHCl}_{3}\right)$.

${ }^{1} \mathrm{H}$ NMR $\left(700 \mathrm{MHz}, \mathrm{CDCl}_{3}\right): \delta=1.39(\mathrm{~s}, 3 \mathrm{H}, \mathrm{H}-9), 1.59(\mathrm{~s}, 3 \mathrm{H}, \mathrm{Me}), 1.57-1.66(\mathrm{~m}, 2 \mathrm{H}, \mathrm{H}-5), 1.67(\mathrm{~s}, 3 \mathrm{H}, \mathrm{Me})$, $2.04-2.11(\mathrm{~m}, 2 \mathrm{H}, \mathrm{H}-6), 2.54(\mathrm{dd}, J=18.0,4.4 \mathrm{~Hz}, 1 \mathrm{H}, \mathrm{H}-2), 2.84\left(\mathrm{~d}_{\mathrm{br}}, J=4.8 \mathrm{~Hz}, 1 \mathrm{H}, \mathrm{OH}\right), 2.89(\mathrm{dd}, J=$ 18.0, 6.9 Hz, 1H, H-2), $4.20-4.29(\mathrm{~m}, 1 \mathrm{H}, \mathrm{H}-3), 5.02-5.08$ (m, 1H, H-7) ppm.

${ }^{13} \mathrm{C} \mathrm{NMR}\left(176 \mathrm{MHz}, \mathrm{CDCl}_{3}\right.$ ): $\delta=17.8$ (Me), 18.6 (C-9), 22.5 (C-6), 25.7 (Me), 38.2 (C-2), 39.4 (C-5), 72.6 (C3), 90.2 (C-4), 123.1 (C-7), 132.9 (C-8), 175.2 (C-1) ppm.

HRMS (ESI, pos.): $m / z$ calcd for $\mathrm{C}_{11} \mathrm{H}_{18} \mathrm{O}_{3} \mathrm{Na}^{+}\left[\mathrm{M}+\mathrm{Na}^{+}\right]: 221.1148$, found 221.1146.

cis-Lactone SI-2 (minor diastereomer)

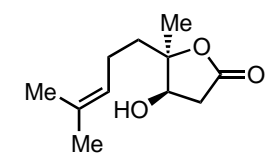

$[\alpha]_{D}^{21}=+21.3\left(c=1.00, \mathrm{CHCl}_{3}\right)$.

${ }^{1} \mathrm{H}$ NMR $\left(700 \mathrm{MHz}, \mathrm{CDCl}_{3}\right): \delta=1.33(\mathrm{~s}, 3 \mathrm{H}, \mathrm{H}-9), 1.61$ (s, 3H, Me), 1.68 (s, 3H, Me), 1.77 (ddd, $J=14.0,10.2$, $6.7 \mathrm{~Hz}, 1 \mathrm{H}, \mathrm{H}-5$ ), 1.83 (ddd, $J=14.0,9.8,6.1 \mathrm{~Hz}, 1 \mathrm{H}, \mathrm{H}-5), 2.05-2.16(\mathrm{~m}, 2 \mathrm{H}, \mathrm{H}-6), 2.50$ (dd, $J=18.1$, $2.4 \mathrm{~Hz}, 1 \mathrm{H}, \mathrm{H}-2), 2.78\left(\mathrm{~d}_{\mathrm{br}}, J=4.7 \mathrm{~Hz}, 1 \mathrm{H}, \mathrm{OH}\right), 2.93(\mathrm{dd}, J=18.1,6.2 \mathrm{~Hz}, 1 \mathrm{H}, \mathrm{H}-2), 4.15-4.20(\mathrm{~m}, 1 \mathrm{H}, \mathrm{H}-3)$, $5.10-5.17(\mathrm{~m}, 1 \mathrm{H}, \mathrm{H}-7) \mathrm{ppm}$.

${ }^{13} \mathrm{C}$ NMR (176 MHz, CDCl $)$ ): $\delta=17.8$ (Me), 22.5 (C-6), 23.2 (C-9), 25.8 (Me), 34.1 (C-5), 38.6 (C-2), 74.6 (C3), 90.0 (C-4), 123.5 (C-7), 133.0 (C-8), 175.5 (C-1) ppm.

The spectroscopic data is in accordance with the literature. ${ }^{8}$

\section{3 (5R)-5-Methyl-5-(4-methylpent-3-ene-1-yl)-3-oxolen-2-one (7)}<smiles>CC(C)=CCC1(C)OC(=O)CC1O</smiles>

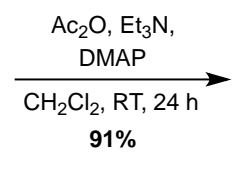<smiles>CC(C)=CCCC1([N+](=O)[O-])C=CC(=O)O1</smiles>

To a flame-dried Schlenk flask containing a solution of lactone SI-2 (3.65 g, $18.4 \mathrm{mmol}, 1.0$ equiv) in anhydrous $\mathrm{CH}_{2} \mathrm{Cl}_{2}(26 \mathrm{~mL})$ under an argon atmosphere were added $\mathrm{Ac}_{2} \mathrm{O}(6.97 \mathrm{~mL}, 74.1 \mathrm{mmol}, 4.0$ equiv), $\mathrm{Et}_{3} \mathrm{~N}(25.7 \mathrm{~mL}, 185 \mathrm{mmol}, 10$ equiv) and 4-(dimethylamino)pyridine (112 mg, $917 \mu \mathrm{mol}, 5 \mathrm{~mol} \%$ ). The reaction mixture was stirred for $24 \mathrm{~h}$ at ambient temperature. The reaction was quenched by the addition of saturated aqueous $\mathrm{NaHCO}_{3}(20 \mathrm{~mL})$, the layers were seperated and the aqueous phase was extracted with $\mathrm{Et}_{2} \mathrm{O}(3 \times 20 \mathrm{~mL})$. The combined organic layers were dried over anhydrous $\mathrm{Na}_{2} \mathrm{SO}_{4}$, filtered and concentrated under reduced pressure. The crude product was purified by column chromatography $\left(\mathrm{SiO}_{2}\right.$, pentane/EtOAc, 4:1) to afford butenolide 7 ( $3.01 \mathrm{~g}, 16.7 \mathrm{mmol}, 91 \%)$ as a colorless oil.

\section{One-pot procedure from nitrile 6}<smiles>CC(C)=CCC[C@@]([C@@H](C)O)([C@H](O)CC#N)[N+]([O-])([O-])O</smiles>

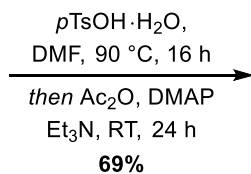<smiles>CC(C)=CCCC1([N+](=O)[O-])C=CC(=O)O1</smiles>

A solution of diastereomeric nitrile $7(293 \mathrm{mg}, 1.49 \mathrm{mmol}, 1.0$ equiv) and para-toluenesulfonic acid monohydrate $(2.83 \mathrm{~g}, 14.9 \mathrm{mmol}, 10$ equiv) in anhydrous $\mathrm{N}, \mathrm{N}$-dimethylformamide $(6 \mathrm{~mL})$ under an argon atmosphere was heated to $90^{\circ} \mathrm{C}$ and stirred for $16 \mathrm{~h}$. After TLC analysis indicated complete consumption 
of the starting material, $\mathrm{Ac}_{2} \mathrm{O}(2.81 \mathrm{~mL}, 29.7 \mathrm{mmol}, 20$ equiv), 4-(dimethylamino)pyridine ( $36.3 \mathrm{mg}$, $297 \mu \mathrm{mol}, 20 \mathrm{~mol} \%)$ and $\mathrm{Et}_{3} \mathrm{~N}(4.12 \mathrm{~mL}, 29.7 \mathrm{mmol}, 20$ equiv) were added and stirring was continued for $24 \mathrm{~h}$. The reaction was quenched by the addition of saturated aqueous $\mathrm{NaHCO}_{3}(10 \mathrm{~mL})$, the layers were seperated and the aqueous phase was extracted with $\mathrm{Et}_{2} \mathrm{O}(5 \times 10 \mathrm{~mL})$. The combined organic extracts were washed with brine $(20 \mathrm{~mL})$, dried over anhydrous $\mathrm{Na}_{2} \mathrm{SO}_{4}$ and concentrated under reduced pressure. The crude product was purified by column chromatography $\left(\mathrm{SiO}_{2}\right.$, pentane/EtOAc, $\left.4: 1\right)$ to afford butenolide 7 (186 mg, $1.03 \mathrm{mmol}, 69 \%$ ) as a colorless oil.

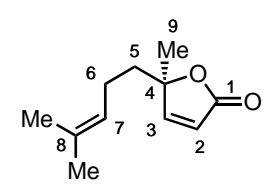

$[\alpha]_{\mathrm{D}}^{20}=-95.6\left(c=1.00, \mathrm{CHCl}_{3}\right)$.

${ }^{1} \mathrm{H}$ NMR $\left(700 \mathrm{MHz}, \mathrm{CDCl}_{3}\right): \delta=1.46(\mathrm{~s}, 3 \mathrm{H}, \mathrm{H}-9), 1.56-1.57(\mathrm{~m}, 3 \mathrm{H}, \mathrm{Me}), 1.66-1.67(\mathrm{~m}, 3 \mathrm{H}, \mathrm{Me}), 1.72$ (ddd, $J=14.0,10.7,5.2 \mathrm{~Hz}, 1 \mathrm{H}, \mathrm{H}-5$ ), 1.85 (ddd, $J=14.0 \mathrm{~Hz}, 10.5,5.4 \mathrm{~Hz}, 1 \mathrm{H}, \mathrm{H}-5), 1.88-1.94(\mathrm{~m}, 1 \mathrm{H}, \mathrm{H}-$ 6), $1.96-2.03(\mathrm{~m}, 1 \mathrm{H}, \mathrm{H}-6), 5.00-5.04(\mathrm{~m}, 1 \mathrm{H}, \mathrm{H}-7), 6.00(\mathrm{~d}, J=5.6 \mathrm{~Hz}, 1 \mathrm{H}, \mathrm{H}-2), 7.34(\mathrm{~d}, J=5.6 \mathrm{~Hz}, 1 \mathrm{H}$, $\mathrm{H}-3) \mathrm{ppm}$.

${ }^{13} \mathrm{C} \mathrm{NMR}\left(176 \mathrm{MHz}, \mathrm{CDCl}_{3}\right.$ ): $\delta$ = 17.8 (Me), 22.6 (C-6), 24.2 (C-9), 25.8 (Me), 38.4 (C-5), 89.0 (C-4), 120.6 (C2), 123.0 (C-7), 132.9 (C-8), 160.4 (C-3), 172.7 (C-1) ppm.

HRMS (ESI, pos.): $\mathrm{m} / \mathrm{z}$ calcd for $\mathrm{C}_{11} \mathrm{H}_{16} \mathrm{O}_{2} \mathrm{~K}^{+}\left[\mathrm{M}+\mathrm{K}^{+}\right]: 219.0782$, found 219.0793 .

The spectroscopic data is in accordance with the literature. ${ }^{9}$

2.4 (5R)-5-Methyl-5-(3-oxoprop-1-yl)-3-oxolen-2-one (SI-3)

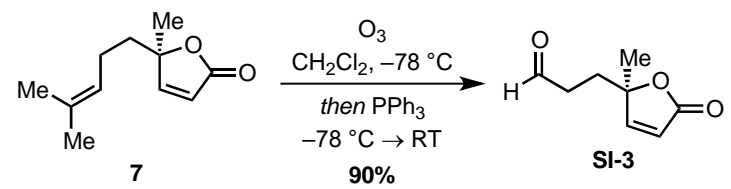

A solution of butenolide $7\left(1.40 \mathrm{~g}, 7.77 \mathrm{mmol}, 1.0\right.$ equiv) in $\mathrm{CH}_{2} \mathrm{Cl}_{2}(77 \mathrm{~mL})$ was cooled to $-78^{\circ} \mathrm{C}$ and a stream of ozone was passed through until a blue colour persisted. The excess ozone was then removed by saturating the solution with oxygen until the blue colour faded and triphenylphosphine $(2.44 \mathrm{~g}$, $9.30 \mathrm{mmol}, 1.2$ equiv) was added. The cooling bath was removed and the reaction mixture was warmed to ambient temperature. The crude solution was dry-loaded onto silica and purified by column chromatography $\left(\mathrm{SiO}_{2}\right.$, pentane/EtOAc, 4:1 to 1:1 to 0:1) to afford aldehyde $\mathbf{S I - 3}(1.08 \mathrm{~g}, 7.00 \mathrm{mmol}, 90 \%)$ as a colorless oil.

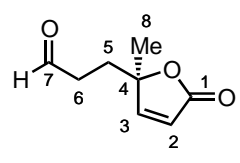

$[\alpha]_{\mathrm{D}}^{22}=-51.1\left(c=1.00, \mathrm{CHCl}_{3}\right)$.

${ }^{1} \mathrm{H}$ NMR $\left(700 \mathrm{MHz}, \mathrm{CDCl}_{3}\right): \delta=1.48(\mathrm{~s}, 3 \mathrm{H}, \mathrm{H}-8), 2.08$ (ddd, $\left.J=14.6,8.2,6.5 \mathrm{~Hz}, 1 \mathrm{H}, \mathrm{H}-5\right), 2.15$ (ddd, $J=$ 14.6, 8.1, $6.0 \mathrm{~Hz}, 1 \mathrm{H}, \mathrm{H}-5$ ), 2.39 (dddd, $J=18.7,8.1,6.5,0.9 \mathrm{~Hz}, 1 \mathrm{H}, \mathrm{H}-6$ ), 2.50 (dddd, $J=18.7,8.2,6.0$, $0.9 \mathrm{~Hz}, 1 \mathrm{H}, \mathrm{H}-6), 6.01(\mathrm{~d}, J=5.6 \mathrm{~Hz}, 1 \mathrm{H}, \mathrm{H}-2), 7.31(\mathrm{~d}, J=5.6 \mathrm{~Hz}, 1 \mathrm{H}, \mathrm{H}-3), 9.71(\mathrm{t}, J=0.9 \mathrm{~Hz}, 1 \mathrm{H}, \mathrm{H}-7) \mathrm{ppm}$.

${ }^{13} \mathrm{C} \mathrm{NMR}\left(176 \mathrm{MHz}, \mathrm{CDCl}_{3}\right.$ ): $\delta=24.3$ (C-8), 29.7 (C-5), 38.0 (C-6), 87.8 (C-4), 121.0 (C-2), 160.0 (C-3), 172.2 (C-1), 200.5 (C-7) ppm.

HRMS (ESI, pos.): $m / z$ calcd for $\mathrm{C}_{8} \mathrm{H}_{10} \mathrm{O}_{3} \mathrm{Na}^{+}\left[\mathrm{M}+\mathrm{Na}^{+}\right]: 177.0522$, found 177.0515 .

The spectroscopic data is in accordance with the literature. ${ }^{9}$ 


\section{5 (5R)-5-Methyl-5-(2-methylene-3-oxoprop-1-yl)-3-oxolen-2-one (SI-4)}

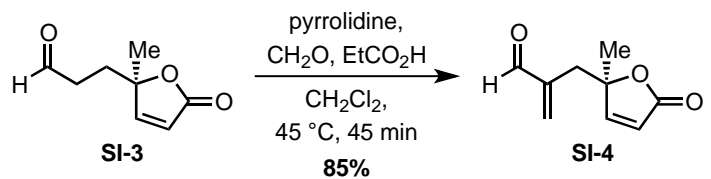

Enal SI-4 was prepared in analogy to a reported procedure by PIHKO et al. for the $\alpha$-methylenation of aldehydes. ${ }^{10} \mathrm{~A}$ solution of aldehyde $\mathbf{S I - 3}(500 \mathrm{mg}, 3.24 \mathrm{mmol}, 1.0$ equiv), aqueous formaldehyde ( $37 \mathrm{wt} \%$, $362 \mu \mathrm{L}, 4.87 \mathrm{mmol}, 1.5$ equiv), propionic acid $(24.0 \mu \mathrm{L}, 324 \mu \mathrm{mol}, 10 \mathrm{~mol} \%)$ and pyrrolidine $(27.0 \mu \mathrm{L}$, $324 \mu \mathrm{mol}, 10 \mathrm{~mol} \%)$ in $\mathrm{CH}_{2} \mathrm{Cl}_{2}(13 \mathrm{~mL})$ was heated to $45^{\circ} \mathrm{C}$ and stirred for $1 \mathrm{~h}$. The mixture was cooled to $0{ }^{\circ} \mathrm{C}$, diluted with EtOAc $(10 \mathrm{~mL})$ and carefully quenched with saturated aqueous $\mathrm{NaHCO}_{3}(10 \mathrm{~mL})$. The layers were seperated and the aqueous phase was extracted with EtOAc $(3 \times 10 \mathrm{~mL})$. The combined organic layers were dried over anhydrous $\mathrm{Na}_{2} \mathrm{SO}_{4}$, filtered and concentrated under reduced pressure. The residue was purified by column chromatography $\left(\mathrm{SiO}_{2}\right.$, pentane/Et ${ }_{2} \mathrm{O}, 4: 1$ to $\left.1: 2\right)$ to afford enal SI-4 (456 mg, $2.74 \mathrm{mmol}, 85 \%$ ) as a colorless oil.

\section{One-pot procedure from butenolide 7}<smiles>CC(C)=CCCC1([O-])C=CC(=O)O1</smiles>

7

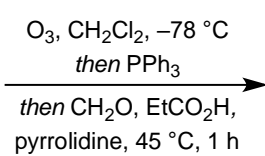

$68 \%$

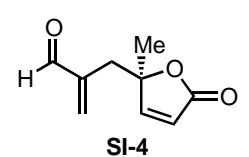

SI-4

A solution of butenolide 7 (190 mg, $1.05 \mathrm{mmol}, 1.0$ equiv) in $\mathrm{CH}_{2} \mathrm{Cl}_{2}\left(2.5 \mathrm{~mL}\right.$ ) was cooled to $-78^{\circ} \mathrm{C}$ and a stream of ozone was passed through until a blue colour persisted. The excess ozone was then removed by saturating the solution with oxygen until the blue colour faded and triphenylphosphine $(276 \mathrm{mg}$, $1.05 \mathrm{mmol}, 1.0$ equiv) was added. The cooling bath was removed and the reaction mixture was warmed to ambient temperature. Then aqueous formaldehyde solution ( $37 \mathrm{wt} \%, 118 \mu \mathrm{L}, 1.58 \mathrm{mmol}, 1.5$ equiv), propionic acid ( $8 \mu \mathrm{L}, 105 \mu \mathrm{mmol}, 10 \mathrm{~mol} \%)$ and pyrrolidine ( $35 \mu \mathrm{L}, 422 \mu \mathrm{mol}, 40 \mathrm{~mol} \%)$ were added and stirring was continued at $45^{\circ} \mathrm{C}$ for $1 \mathrm{~h}$. The mixture was cooled to $0{ }^{\circ} \mathrm{C}$, diluted with EtOAc $(5 \mathrm{~mL})$ and carefully quenched with saturated aqueous $\mathrm{NaHCO}_{3}(5 \mathrm{~mL})$. The layers were seperated and the aqueous phase was extracted with EtOAc $(3 \times 5 \mathrm{~mL})$. The combined organic layers were dried over anhydrous $\mathrm{Na}_{2} \mathrm{SO}_{4}$, filtered and concentrated under reduced pressure. The residue was purified by MPLC (dry-loaded onto Celite ${ }^{\circledR}, \mathrm{SiO}_{2}$, cyclohexane/EtOAc, 100:0 to 4:1 to 1:1) to afford enal SI-4 (119 mg, $\left.713 \mu \mathrm{mol}, 68 \%\right)$ as a colorless oil.

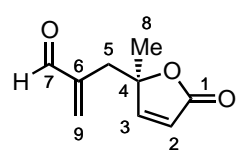

$[\alpha]_{\mathrm{D}}^{20}=-4.4\left(c=1.00, \mathrm{CHCl}_{3}\right)$.

${ }^{1}{ }^{H}$ NMR $\left(500 \mathrm{MHz}, \mathrm{CDCl}_{3}\right): \delta=1.52(\mathrm{~s}, 3 \mathrm{H}, \mathrm{H}-8), 2.68(\mathrm{~d}, J=13.7 \mathrm{~Hz}, 1 \mathrm{H}, \mathrm{H}-5), 2.88(\mathrm{~d}, J=13.7 \mathrm{~Hz}, 1 \mathrm{H}, \mathrm{H}-$ 5), $5.88(\mathrm{~d}, J=5.6 \mathrm{~Hz}, 1 \mathrm{H}, \mathrm{H}-2), 6.19(\mathrm{~s}, 1 \mathrm{H}, \mathrm{H}-9), 6.49(\mathrm{~s}, 1 \mathrm{H}, \mathrm{H}-9), 7.24(\mathrm{~d}, J=5.6 \mathrm{~Hz}, 1 \mathrm{H}, \mathrm{H}-3), 9.41(\mathrm{~s}, 1$ $\mathrm{H}, \mathrm{H}-7) \mathrm{ppm}$.

${ }^{13} \mathrm{C}$ NMR (126 MHz, CDCl 3 ): $\delta=24.5$ (C-8), 35.4 (C-5), 87.3 (C-4), 120.9 (C-2), 140.2 (C-9), 143.0 (C-6), 159.5 (C-3), 172.3 (C-1), 194.2 (C-7) ppm.

HRMS (ESI, pos.): $m / z$ calcd for $\mathrm{C}_{9} \mathrm{H}_{10} \mathrm{O}_{3} \mathrm{Na}^{+}\left[\mathrm{M}+\mathrm{Na}^{+}\right]:$189.0522, found 189.0526 .

2.6 (5R)-5-Methyl-5-(3-(acetyloxy)-2-methyleneprop-1-yl)-3-oxolen-2-one (4)<smiles>C=C(C=O)CC1(C)C=CC(=O)O1</smiles>

SI-4

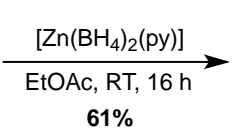

$61 \%$<smiles>C=C(COC(C)=O)CC1(C)C=CC(=O)O1</smiles>

4 
Allyl acetate 4 was prepared in analogy to a reported procedure by ZEYNIZADEH and SETAMDIDEH for the reductive acetylation of carbonyl compounds. ${ }^{11}$ To a solution of enal SI-4 $(270 \mathrm{mg}, 1.63 \mathrm{mmol}, 1.0$ equiv) in anhydrous EtOAc $(4.6 \mathrm{~mL})$ at $0{ }^{\circ} \mathrm{C}$ was added zinc borohydride pyridine complex $(297 \mathrm{mg}, 1.71 \mathrm{mmol}$, 1.05 equiv). The resulting reaction mixture was warmed to ambient temperature and stirred for $16 \mathrm{~h}$. The reaction was carefully quenched with saturated aqueous $\mathrm{NH}_{4} \mathrm{Cl}(5 \mathrm{~mL})$. The layers were seperated and the aqueous phase was extracted with EtOAc $(3 \times 5 \mathrm{~mL})$. The combined organic layers were dried over anhydrous $\mathrm{Na}_{2} \mathrm{SO}_{4}$, filtered and concentrated under reduced pressure. Purification by column chromatography $\left(\mathrm{SiO}_{2}\right.$, pentane/Et $2 \mathrm{O}, 2: 1$ to $1: 2$ ) afforded allyl acetate 4 (209 $\mathrm{mg}, 994 \mu \mathrm{mol}, 61 \%$ ) as a colorless oil.

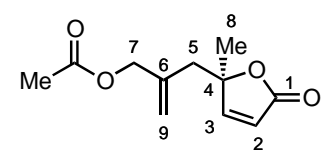

$[\alpha]_{D}^{20}=-10.2\left(c=1.00, \mathrm{CHCl}_{3}\right)$.

${ }^{1} \mathrm{H}$ NMR $\left(500 \mathrm{MHz}, \mathrm{CDCl}_{3}\right): \delta=1.49(\mathrm{~s}, 3 \mathrm{H}, \mathrm{H}-8), 2.09(\mathrm{~s}, 3 \mathrm{H}, \mathrm{Ac}), 2.45(\mathrm{~d}, J=14.3 \mathrm{~Hz}, 1 \mathrm{H}, \mathrm{H}-5), 2.59(\mathrm{~d}, J=$ 14.3 Hz, $1 \mathrm{H}, \mathrm{H}-5), 4.49(\mathrm{~s}, 2 \mathrm{H}, \mathrm{H}-7), 5.05-5.07(\mathrm{~m}, 1 \mathrm{H}, \mathrm{H}-9), 5.24-5.25(\mathrm{~m}, 1 \mathrm{H}, \mathrm{H}-9), 6.03(\mathrm{~d}, J=5.6 \mathrm{~Hz}$, $1 \mathrm{H}, \mathrm{H}-2), 7.38(\mathrm{~d}, J=5.6 \mathrm{~Hz}, 1 \mathrm{H}, \mathrm{H}-3) \mathrm{ppm}$.

${ }^{13} \mathrm{C} \mathrm{NMR}\left(126 \mathrm{MHz}, \mathrm{CDCl}_{3}\right.$ ): $\delta=21.0$ (AC), 24.1 (C-8), 41.9 (C-5), 66.9 (C-7), 88.0 (C-4), 118.9 (C-9), 121.2 (C2), 137.6 (C-6), 159.7 (C-3), 170.7 (AC), 172.2 (C-1) ppm.

HRMS (ESI, pos.): $\mathrm{m} / z$ calcd for $\mathrm{C}_{11} \mathrm{H}_{14} \mathrm{O}_{4} \mathrm{Na}^{+}\left[\mathrm{M}+\mathrm{Na}^{+}\right]: 233.0784$, found 233.0787; calcd for $\mathrm{C}_{11} \mathrm{H}_{14} \mathrm{O}_{4} \mathrm{~K}^{+}$ $\left[\mathrm{M}+\mathrm{K}^{+}\right]$: 249.0524, found 249.0530 .

\section{7 (5R)-5-Methyl-5-(12-phenyl-2-methylenedodec-1-yl)-3-oxolen-2-one (3)}

\section{Palladium-catalyzed allylic substitution with hydrazone 8}

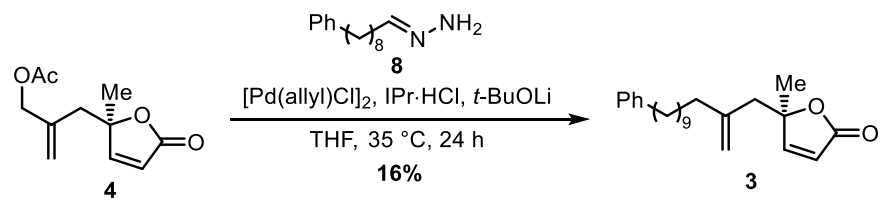

The following procedure was done in analogy to a reported protocol by $\mathrm{LI}$ et al. for the palladiumcatalyzed alkylation of allyl acetates with hydrazones. ${ }^{12}$

Preparation of the hydrazone 8: A mixture of 9-phenylnonanal (324 mg, $1.48 \mathrm{mmol}, 1.0$ equiv), hydrazine monohydrate ( $86.5 \mu \mathrm{L}, 1.79 \mathrm{mmol}, 1.2$ equiv) and anhydrous $\mathrm{Na}_{2} \mathrm{SO}_{4}(120 \mathrm{mg})$ in THF (1.2 mL) was stirred at ambient temperature for $2 \mathrm{~h}$. Then $5 \AA$ molecular sieves powder $(150 \mathrm{mg})$ was added and the solution was dried over night.

A flame-dried Schlenk tube was charged with 1,3-bis(2,6-diisopropylphenyl)imidazolium chloride (10.0 mg, $24.0 \mu \mathrm{mol}, 10 \mathrm{~mol} \%$ ) and allylpalladium(II) chloride dimer $(4.40 \mathrm{mg}, 12.0 \mu \mathrm{mol}, 5 \mathrm{~mol} \%)$ under an argon atmosphere. A solution of $t$-BuOLi ( $1 \mathrm{M}$ in THF, $48.0 \mu \mathrm{L}, 48.0 \mu \mathrm{mol}, 20 \mathrm{~mol} \%)$ was added and the mixture was stirred at ambient temperature for $1 \mathrm{~h}$. Then a solution of allyl acetate $4(50.0 \mathrm{mg}, 238 \mu \mathrm{mol}$, 1.0 equiv) in THF $(0.71 \mathrm{~mL}$ ) was added and the mixture stirred for another $30 \mathrm{~min}$ before a solution of hydrazone 8 (1.25 M in THF, $0.24 \mathrm{~mL}, 300 \mu \mathrm{mol}, 1.26$ equiv) and $t$-BuOLi ( $1 \mathrm{M} \mathrm{in} \mathrm{THF,} 480 \mu \mathrm{L}, 480 \mu \mathrm{mol}$, 2.0 equiv) were added. The reaction mixture was stirred at $35^{\circ} \mathrm{C}$ for $24 \mathrm{~h}$ and then filtered through a short pad of Celite ${ }^{\circledR}$, rinsing with $\mathrm{CH}_{2} \mathrm{Cl}_{2}(3 \times 5 \mathrm{~mL})$. The solvent was removed under reduced pressure and the crude product was purified by column chromatography $\left(\mathrm{SiO}_{2}\right.$, pentane/EtOAc, 8:1 to 6:1) to afford alkene 3 (13.8 mg, $389 \mu \mathrm{mol}, 16 \%)$ as a colorless oil.

Iron-catalyzed allylic substitution with Grignard reagent 9 


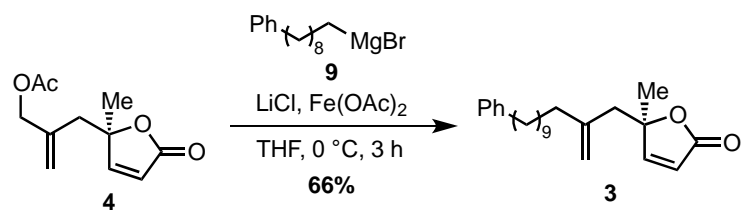

Preparation of the Grignard reagent (9-phenylnonylmagnesium bromide (9)): To a flame-dried Schlenk flask was added freshly ground magnesium $(146 \mathrm{mg}, 6.00 \mathrm{mmol}, 1.5$ equiv) and the flask was once more dried by heating with a heat gun under high vacuum while vigorously stirring the magnesium. After cooling to ambient temperature the vessel was placed under an argon atmosphere and a solution of (9bromononyl)benzene ( $1.13 \mathrm{~g}, 4.00 \mathrm{mmol}, 1.0$ equiv) in anhydrous THF ( $3 \mathrm{~mL})$ was slowly added over a period of $1 \mathrm{~h}$. Stirring was continued for $16 \mathrm{~h}$ and then stopped. After the solids settled down, the clear solution was transferred with a syringe into another flame-dried Schlenk flask and stored under an argon atmosphere. The concentration was determined by titration with menthol in the presence of phenanthroline. ${ }^{13}$

Alkene 3 was prepared in analogy to a procedure by JACOBI VON WANGELIN et al. for the iron-catalyzed alkylation of allyl acetates with alkylmagnesium compounds. ${ }^{14}$ A Schlenk tube was charged with anhydrous $\mathrm{Fe}(\mathrm{OAC})_{2}(4.9 \mathrm{mg}, 28 \mu \mathrm{mol}, 10 \mathrm{~mol} \%)$ and anhydrous $\mathrm{LiCl}(16.6 \mathrm{mg}, 392 \mu \mathrm{mol}, 1.4$ equiv) and flame-dried under high vacuum until bubbling ceased. Then a solution of allyl acetate $4(58.8 \mathrm{mg}$, $280 \mu \mathrm{mol}, 1.0$ equiv) in THF $(1.3 \mathrm{~mL})$ was added and the resulting mixture was cooled to $0{ }^{\circ} \mathrm{C}$. The Grignard reagent $9(0.9 \mathrm{M}, 0.44 \mathrm{~mL}, 1.4$ equiv) was added dropwise over a period of $2 \mathrm{~h}$ and stirring was continued for further $1 \mathrm{~h}$ at $0{ }^{\circ} \mathrm{C}$. The reaction was quenched by the addition of $1 \mathrm{M} \mathrm{HCl}(2 \mathrm{~mL})$ and the aqueous phase was extracted with EtOAc $(3 \times 2 \mathrm{~mL})$. The combined organic layers were washed with brine $(2 \mathrm{~mL})$, dried over anhydrous $\mathrm{Na}_{2} \mathrm{SO}_{4}$ and concentrated under reduced pressure. The crude product was purified by MPLC (dry-loaded onto Celite ${ }^{\circledR}, \mathrm{SiO}_{2}$, cyclohexane/EtOAc, 100:1 to 10:1 to 6:1) to afford alkene 3 (65.4 mg, $185 \mu \mathrm{mol}, 66 \%)$ as a colorless oil.

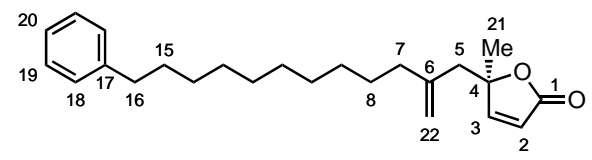

$[\alpha]_{D}^{24}=-12.3\left(c=1.00, \mathrm{CHCl}_{3}\right)$.

${ }^{1} \mathrm{H}$ NMR $\left(700 \mathrm{MHz}, \mathrm{CDCl}_{3}\right): \delta=1.21-1.36\left(\mathrm{~m}, 12 \mathrm{H}, \mathrm{CH}_{2}\right), 1.36-1.42(\mathrm{~m}, 2 \mathrm{H}, \mathrm{H}-9), 1.46(\mathrm{~s}, 3 \mathrm{H}, \mathrm{H}-21)$, $1.59-1.64(\mathrm{~m}, 2 \mathrm{H}, \mathrm{H}-15), 2.00(\mathrm{t}, J=7.7 \mathrm{~Hz}, 2 \mathrm{H}, \mathrm{H}-7), 2.40(\mathrm{~d}, J=13.9 \mathrm{~Hz}, 1 \mathrm{H}, \mathrm{H}-5), 2.52(\mathrm{~d}, J=13.9 \mathrm{~Hz}, 1$ $\mathrm{H}, \mathrm{H}-5), 2.60(\mathrm{t}, J=7.7 \mathrm{~Hz}, 2 \mathrm{H}, \mathrm{H}-16), 4.79-4.81(\mathrm{~m}, 1 \mathrm{H}, \mathrm{H}-22), 4.93-4.94(\mathrm{~m}, 1 \mathrm{H}, \mathrm{H}-22), 5.99$ (d, J = 5.6 $\mathrm{Hz}, 1 \mathrm{H}, \mathrm{H}-2), 7.15-7.19(\mathrm{~m}, 3 \mathrm{H}, \mathrm{H}-18, \mathrm{H}-20), 7.26-7.29(\mathrm{~m}, 2 \mathrm{H}, \mathrm{H}-19), 7.35$ (d, J = 5.6 Hz, $1 \mathrm{H}, \mathrm{H}-3$ ) ppm.

${ }^{13} \mathrm{C} \mathrm{NMR}(176 \mathrm{MHz}, \mathrm{CDCl})$ ): $\delta=24.1$ (C-21), $27.9(\mathrm{C}-8), 29.35\left(\mathrm{CH}_{2}\right), 29.44\left(\mathrm{CH}_{2}\right), 29.61\left(\mathrm{CH}_{2}\right), 29.62\left(\mathrm{CH}_{2}\right)$, $29.66\left(\mathrm{CH}_{2}\right), 29.69\left(\mathrm{CH}_{2}\right), 31.6(\mathrm{C}-15), 36.1(\mathrm{C}-16), 37.0(\mathrm{C}-7), 44.9$ (C-5), 88.7 (C-4), $115.4(\mathrm{C}-22), 120.6$ (C2), 125.7 (C-20), 128.3 (C-19), 128.5 (C-18), 143.1 (C-17), 143.6 (C-6), 160.4 (C-3), 172.5 (C-1) ppm.

HRMS (ESI, pos.): $m / z$ calcd for $\mathrm{C}_{24} \mathrm{H}_{34} \mathrm{O}_{2} \mathrm{Na}^{+}\left[\mathrm{M}+\mathrm{Na}^{+}\right]$: 377.2451, found 377.2465.

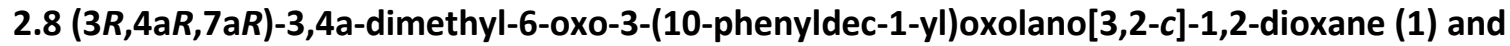 (3S,4aR,7aR)-3,4a-dimethyl-6-oxo-3-(10-phenyldec-1-yl)oxolano[3,2-c]-1,2-dioxane (2)}
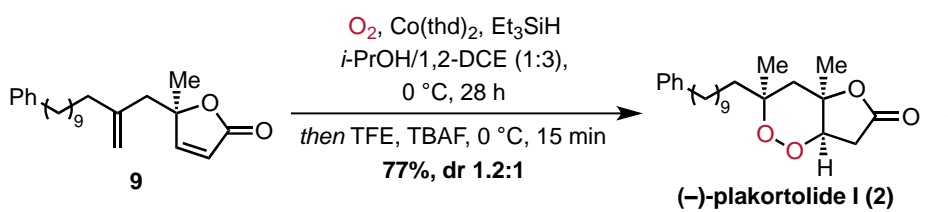

1.2

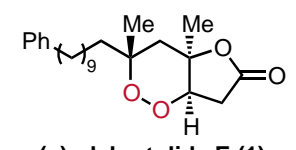

(+)-plakortolide E (1)

A flame-dried Schlenk flask was charged with bis(2,2,6,6-tetramethyl-3,5-heptanedionato)cobalt(II) $(53.3 \mathrm{mg}, 125 \mu \mathrm{mol}, 30 \mathrm{~mol} \%), 1,2$-dichloroethane $(6 \mathrm{~mL})$ and half the amount of $\mathrm{Et}_{3} \mathrm{SiH}(80.0 \mu \mathrm{L}$, $501 \mu \mathrm{mol}, 1.2$ equiv). The solution was saturated with a stream of oxygen for $5 \mathrm{~min}$ and stirred for $1 \mathrm{~h}$ under an atmosphere of oxygen. Then 4 (148 $\mathrm{mg}, 417 \mu \mathrm{mol}, 1.0$ equiv) and $i$-PrOH ( $2 \mathrm{~mL}$ ) were added at 
$0{ }^{\circ} \mathrm{C}$, followed by the dropwise addition of the remaining half of $\mathrm{Et}_{3} \mathrm{SiH}(80.0 \mu \mathrm{L}, 501 \mu \mathrm{mol}, 1.2$ equiv) in 1,2-dichloroethane $(0.05 \mathrm{~mL})$ over $3 \mathrm{~h}$. After stirring for $28 \mathrm{~h}$ the reaction mixture was cooled to $-5^{\circ} \mathrm{C}$ and TFE ( $300 \mu \mathrm{L}, 4.18 \mathrm{mmol}, 10.0$ equiv) and TBAF ( $1 \mathrm{M}, 1.00 \mathrm{~mL}, 2.4$ equiv) were added. The mixture was warmed to $0{ }^{\circ} \mathrm{C}$ and stirred for $15 \mathrm{~min}$ and then diluted with $\mathrm{H}_{2} \mathrm{O}(5 \mathrm{~mL})$. The layers were separated and the aqueous phase was extracted with $\mathrm{CH}_{2} \mathrm{Cl}_{2}(3 \times 5 \mathrm{~mL})$. The combined organic layers were dried over anhydrous $\mathrm{Na}_{2} \mathrm{SO}_{4}$, filtered and concentrated under reduced pressure. The crude product was purified by column chromatography $\left(\mathrm{SiO}_{2}\right.$, pentane $\left./ \mathrm{CH}_{2} \mathrm{Cl}_{2}, 1: 3\right)$ to give $1(57.0 \mathrm{mg}, 147 \mu \mathrm{mol}, 35 \%)$ as a colorless solid and 2 (68.4 $\mathrm{mg}, 176 \mu \mathrm{mol}, 42 \%)$ as a colorless oil.

\section{(+)-Plakortolide E (1)}

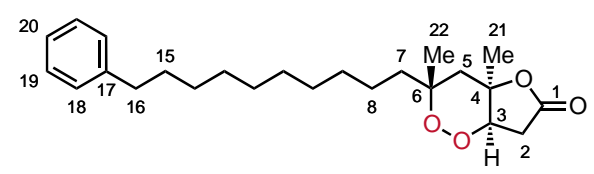

$[\alpha]_{D}^{24}=+10.1\left(c=1.00, \mathrm{CHCl}_{3}\right) ;$ Lit. $^{15}:[\alpha]_{D}=+8.0\left(c=0.0173, \mathrm{CHCl}_{3}\right)$.

${ }^{1} \mathrm{H}$ NMR $\left(700 \mathrm{MHz}, \mathrm{CDCl}_{3}\right): \delta=1.24-1.38\left(\mathrm{~m}, 14 \mathrm{H}, \mathrm{CH}_{2}\right), 1.29(\mathrm{~s}, 2 \mathrm{H}, \mathrm{H}-22), 1.38(\mathrm{~s}, 3 \mathrm{H}, \mathrm{H}-21), 1.46-1.51$ (m, 1H, H-7), $1.51-1.58(\mathrm{~m}, 1 \mathrm{H}, \mathrm{H}-7), 1.59-1.64(\mathrm{~m}, 2 \mathrm{H}, \mathrm{H}-15), 1.71(\mathrm{~d}, J=14.8 \mathrm{~Hz}, 1 \mathrm{H}, \mathrm{H}-5), 2.17(\mathrm{~d}, J=$ $14.8 \mathrm{~Hz}, 1 \mathrm{H}, \mathrm{H}-5), 2.58-2.65(\mathrm{~m}, 3 \mathrm{H}, \mathrm{H}-2, \mathrm{H}-16), 2.91$ (dd, J = 18.5, $6.2 \mathrm{~Hz}, 1 \mathrm{H}, \mathrm{H}-2), 4.45(\mathrm{~d}, J=6.2 \mathrm{~Hz}, 1 \mathrm{H}$, $\mathrm{H}-3), 7.16-7.19$ (m, 3H, H-18, H-20), $7.26-7.29$ (m, 2H, H-19) ppm.

${ }^{13} \mathrm{C} \mathrm{NMR}\left(176 \mathrm{MHz}, \mathrm{CDCl}_{3}\right): \delta=22.5(\mathrm{C}-22), 23.2\left(\mathrm{CH}_{2}\right), 26.0(\mathrm{C}-21), 29.4\left(\mathrm{CH}_{2}\right), 29.59\left(2 \mathrm{C}, \mathrm{CH}_{2}\right), 29.63(2 \mathrm{C}$, $\left.\mathrm{CH}_{2}\right), 30.1\left(\mathrm{CH}_{2}\right), 31.6(\mathrm{C}-15), 34.4(\mathrm{C}-2), 36.1$ (C-16), 40.7 (C-5), 41.1 (C-7), 80.2 (C-6), $81.2(\mathrm{C}-3), 82.9$ (C-4), 125.7 (C-20), 128.3 (2C, C-19), 128.5 (2C, C-18), 143.0 (C-17), 174.4 (C-1) ppm.

HRMS (ESI, pos.): $m / z$ calcd for $\mathrm{C}_{24} \mathrm{H}_{36} \mathrm{O}_{4} \mathrm{Na}^{+}\left[\mathrm{M}+\mathrm{Na}^{+}\right]: 411.2506$, found 411.2522 .

m. p.: $54-55^{\circ} \mathrm{C}$.

X-ray: Crystals were grown by slow evaporation of a solution of $\mathbf{1}$ in pentane and $\mathrm{Et}_{2} \mathrm{O}$ in a $1 \mathrm{~mL}$ vial at ambient temperature.

The spectroscopic data is in accordance with the literature. ${ }^{15}$

\section{(-)-Plakortolide I (2)}

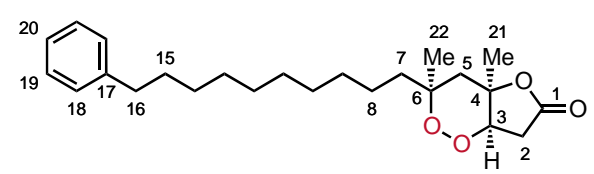

$[\alpha]_{\mathrm{D}}^{24}=-5.8\left(c=1.00, \mathrm{CHCl}_{3}\right) ;$ Lit. $^{16}:[\alpha]_{\mathrm{D}}^{20}=-8\left(c=0.05, \mathrm{CHCl}_{3}\right)$.

${ }^{1} \mathrm{H} \mathrm{NMR}\left(700 \mathrm{MHz}, \mathrm{CDCl}_{3}\right): \delta=1.20(\mathrm{~s}, 3 \mathrm{H}, \mathrm{H}-22), 1.24-1.36\left(\mathrm{~m}, 14 \mathrm{H}, \mathrm{CH}_{2}\right), 1.37(\mathrm{~s}, 3 \mathrm{H}, \mathrm{H}-21), 1.52-1.58$ (m, 1H, H-7), $1.58-1.64(\mathrm{~m}, 2 \mathrm{H}, \mathrm{H}-15), 1.65(\mathrm{~d}, J=15.0 \mathrm{~Hz}, 1 \mathrm{H}, \mathrm{H}-5), 1.70-1.77(\mathrm{~m}, 1 \mathrm{H}, \mathrm{H}-7), 2.27$ (d, J= $15.0 \mathrm{~Hz}, 1 \mathrm{H}, \mathrm{H}-5), 2.56(\mathrm{~d}, J=18.5 \mathrm{~Hz}, 1 \mathrm{H}, \mathrm{H}-2), 2.60(\mathrm{t}, J=7.8 \mathrm{~Hz}, 2 \mathrm{H}, \mathrm{H}-16), 2.90$ (dd, $J=18.5,6.0 \mathrm{~Hz}, 1 \mathrm{H}$, $\mathrm{H}-2$ ), 4.47 (d, J = 6.0 Hz, 1H, H-3), $7.15-7.25$ (m, 3H, H-18, H-20), $7.25-7.29$ (m, 2H, H-19) ppm.

${ }^{13} \mathrm{C} \mathrm{NMR}\left(176 \mathrm{MHz}, \mathrm{CDCl}_{3}\right): \delta=23.8\left(\mathrm{CH}_{2}\right), 25.0(\mathrm{C}-22), 26.0(\mathrm{C}-21), 29.4\left(\mathrm{CH}_{2}\right), 29.59\left(\mathrm{CH}_{2}\right) 29.64\left(2 \mathrm{C}, \mathrm{CH}_{2}\right)$, $29.7\left(\mathrm{CH}_{2}\right), 30.1\left(\mathrm{CH}_{2}\right), 31.6$ (C-15), 34.2 (C-2), 36.1 (C-16), 37.0 (C-7), 40.3 (C-5), 80.3 (C-6), 80.9 (C-3), 82.6 (C-4), 125.6 (C-20), 128.3 (C-19), 128.5 (C-18), 143.1 (C-17), 174.2 (C-1) ppm.

HRMS (ESI, pos.): $\mathrm{m} / z$ calcd for $\mathrm{C}_{24} \mathrm{H}_{36} \mathrm{O}_{4} \mathrm{Na}^{+}\left[\mathrm{M}+\mathrm{Na}^{+}\right]: 411.2506$, found 411.2524 .

The spectroscopic data is in accordance with the literature. ${ }^{16}$ 


\section{X-ray data}

\section{(+)-Plakortolide E (1) (CCDC2074855)}

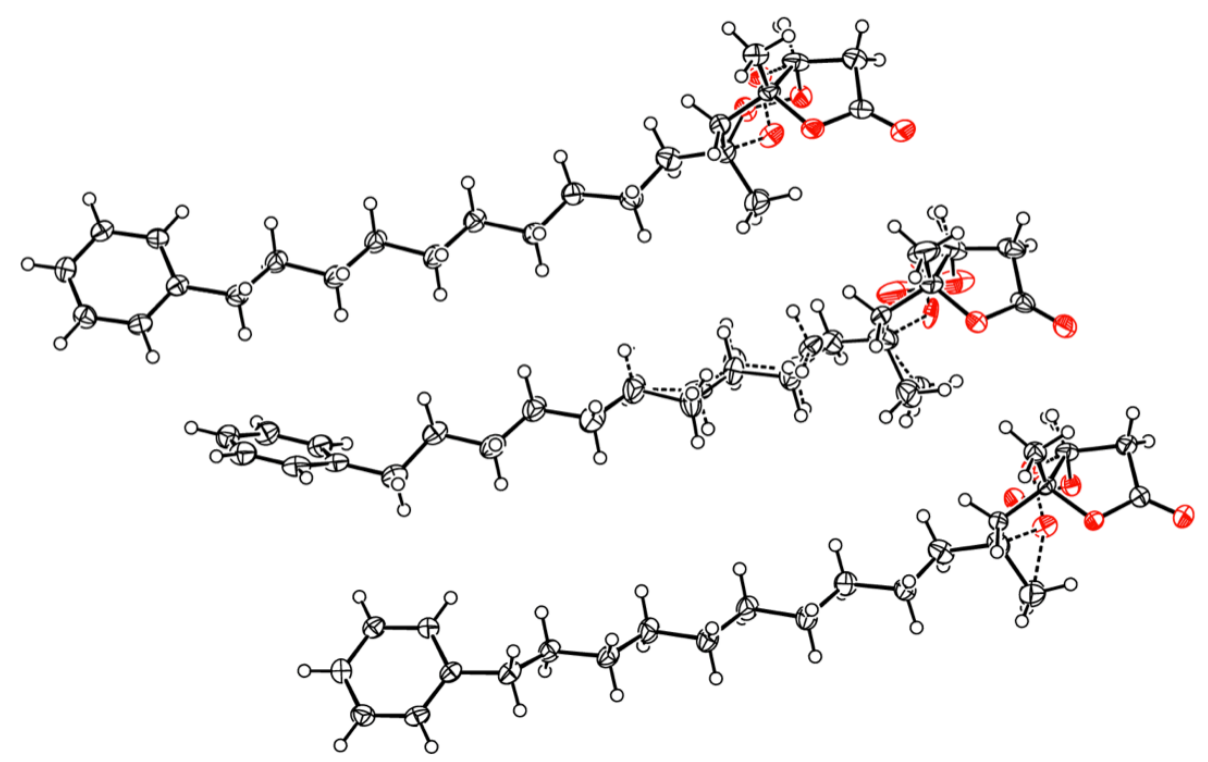

Table S1. Crystal data of (+)-plakortolide E (1).

\begin{tabular}{|c|c|}
\hline Empirical formula & $\mathrm{C}_{72} \mathrm{H}_{108} \mathrm{O}_{12}$ \\
\hline Formula weight & 1165.58 \\
\hline Temperature/K & 100.0 \\
\hline Crystal system & monoclinic \\
\hline Space group & $\mathrm{P} 2_{1}$ \\
\hline $\mathrm{a} / \mathrm{A}$ & $5.7306(2)$ \\
\hline $\mathrm{b} / \AA ̊$ & $17.1506(7)$ \\
\hline$c / \AA ̊ A$ & $34.0117(14)$ \\
\hline$\alpha /^{\circ}$ & 90 \\
\hline$\beta /^{\circ}$ & $93.473(2)$ \\
\hline$\gamma / /^{\circ}$ & 90 \\
\hline Volume/ $/ \AA^{3}$ & $3336.6(2)$ \\
\hline Z & 2 \\
\hline$\rho_{\text {calc }} / \mathrm{gcm}^{-3}$ & 1.160 \\
\hline$\mu / \mathrm{mm}^{-1}$ & 0.611 \\
\hline$F(000)$ & 1272.0 \\
\hline Crystal size $/ \mathrm{mm}^{3}$ & $0.754 \times 0.126 \times 0.052$ \\
\hline Radiation & $\operatorname{CuK} \alpha(\lambda=1.54178)$ \\
\hline $2 \Theta$ range for data collection $/^{\circ}$ & 5.206 to 136.548 \\
\hline Reflections collected & 129589 \\
\hline Independent reflections & $12052\left[R_{\text {int }}=0.0410, R_{\text {sigma }}=0.0174\right]$ \\
\hline Data/restraints/parameters & $12052 / 6 / 860$ \\
\hline Goodness-of-fit on $F^{2}$ & 1.034 \\
\hline Final $R$ indexes $[I>=2 \sigma(I)]$ & $R_{1}=0.0380, w R_{2}=0.0906$ \\
\hline Final $R$ indexes [all data] & $R_{1}=0.0390, w R_{2}=0.0915$ \\
\hline Largst diff. peak and hole/e. $\AA^{-3}$ & 0.45 and -0.63 \\
\hline Flack parameter & $0.02(2)$ \\
\hline CCDC deposition number & 2074855 \\
\hline
\end{tabular}




\section{NMR Spectra}

\section{Nitrile 6}

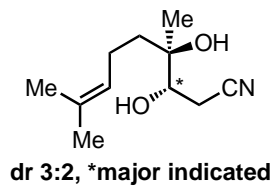

dr 3:2, *major indicated
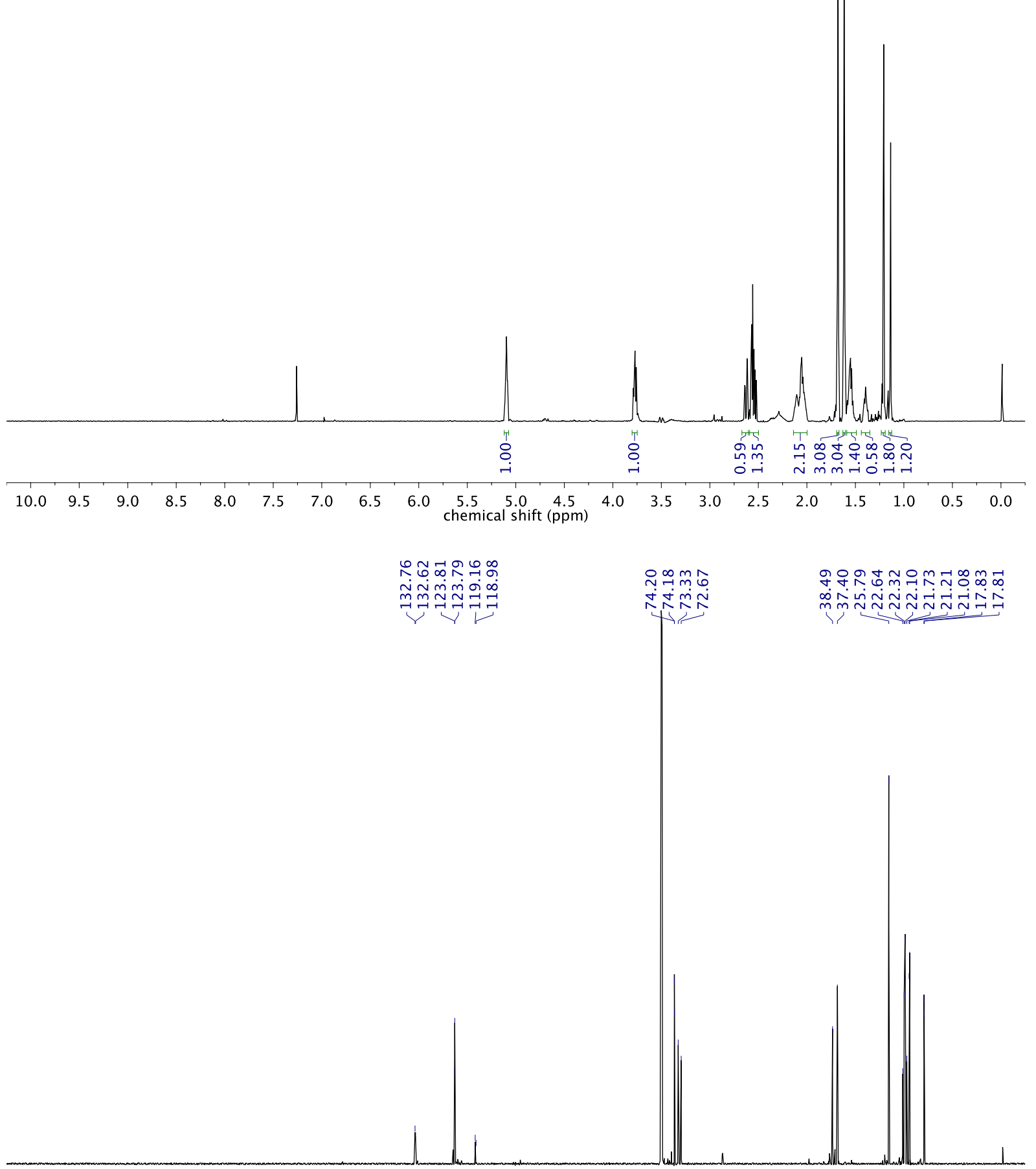

$\begin{array}{llllllllllllllllllll}220 & 210 & 200 & 190 & 180 & 170 & 160 & 150 & 140 & 130 & \begin{array}{c}120 \\ \text { chemical shift }(\mathrm{ppm})\end{array}\end{array}$ 
trans-Lactone SI-2

$\underbrace{\mathrm{Me}}_{\mathrm{Me}}=\mathrm{O}$

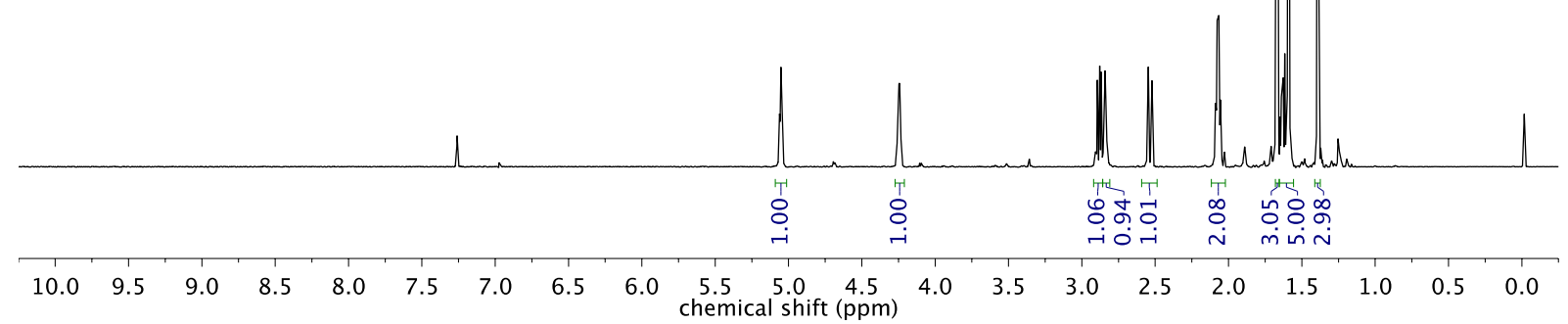

$\underset{\substack{n\\}}{\stackrel{n}{1}}$

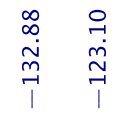

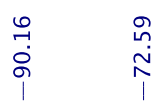

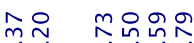

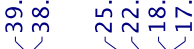

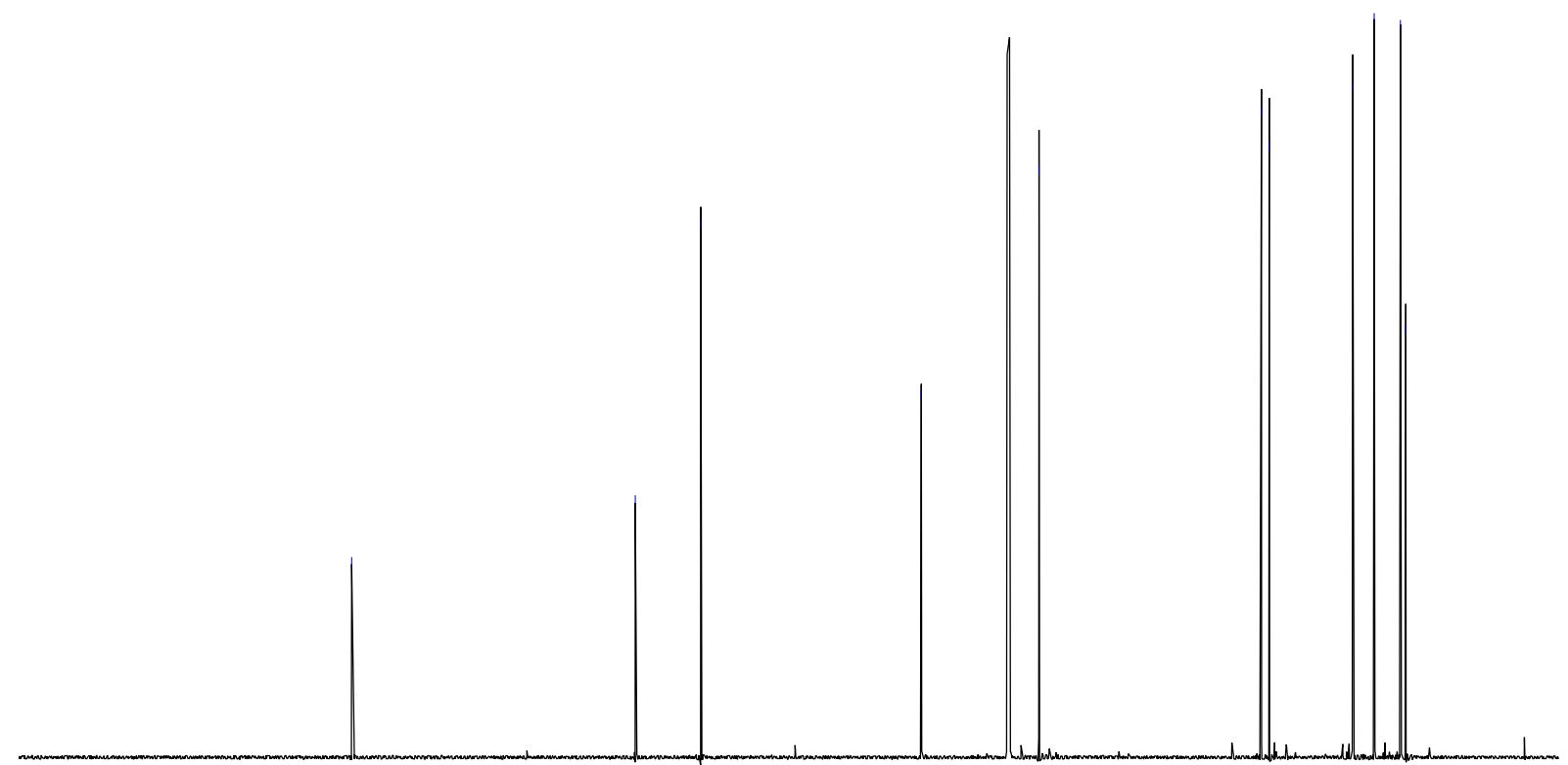

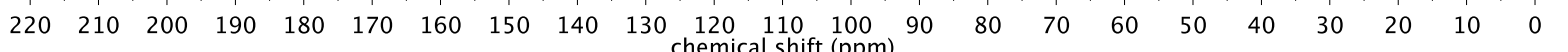


cis-Lactone SI-2

$\mathrm{Me}_{\mathrm{HO}}^{\mathrm{Me}}=\mathrm{O}$
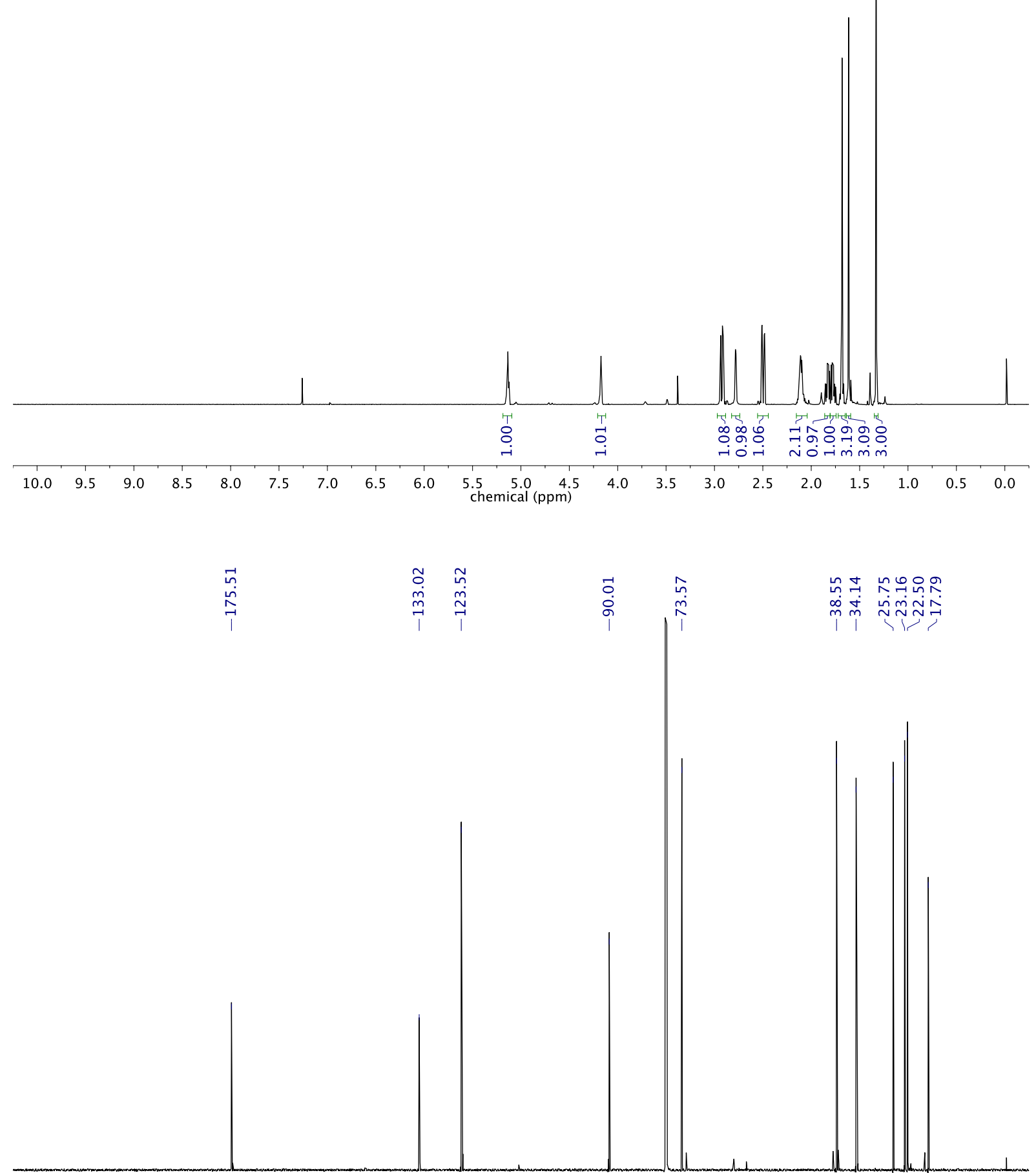

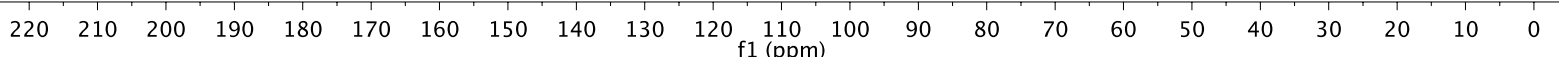




\section{Butenolide 7}<smiles>CC(N)=CCC1(C)C=CC(=O)O1</smiles>

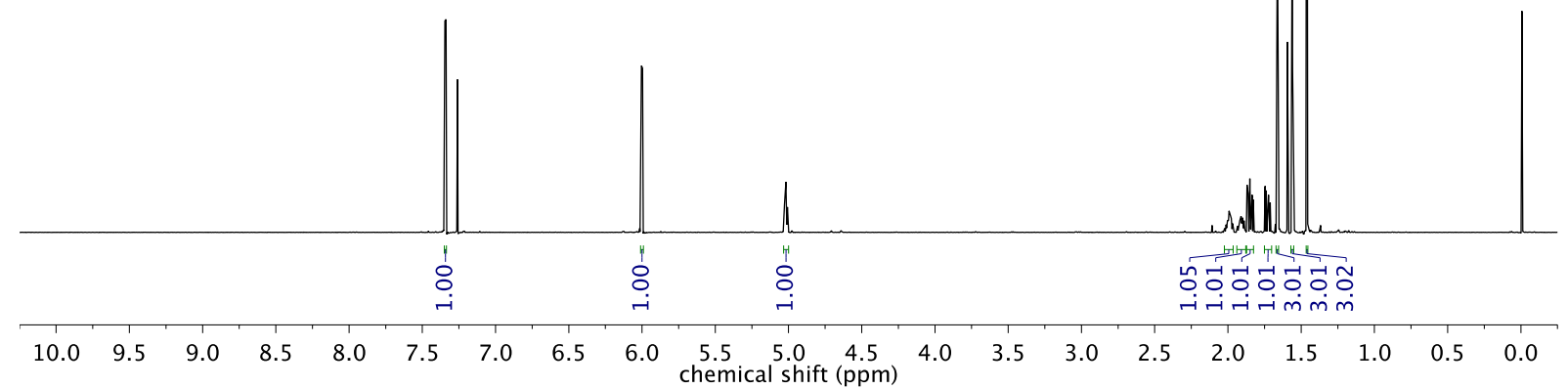

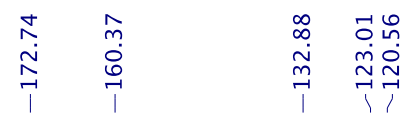




\section{Aldehyde SI-3}
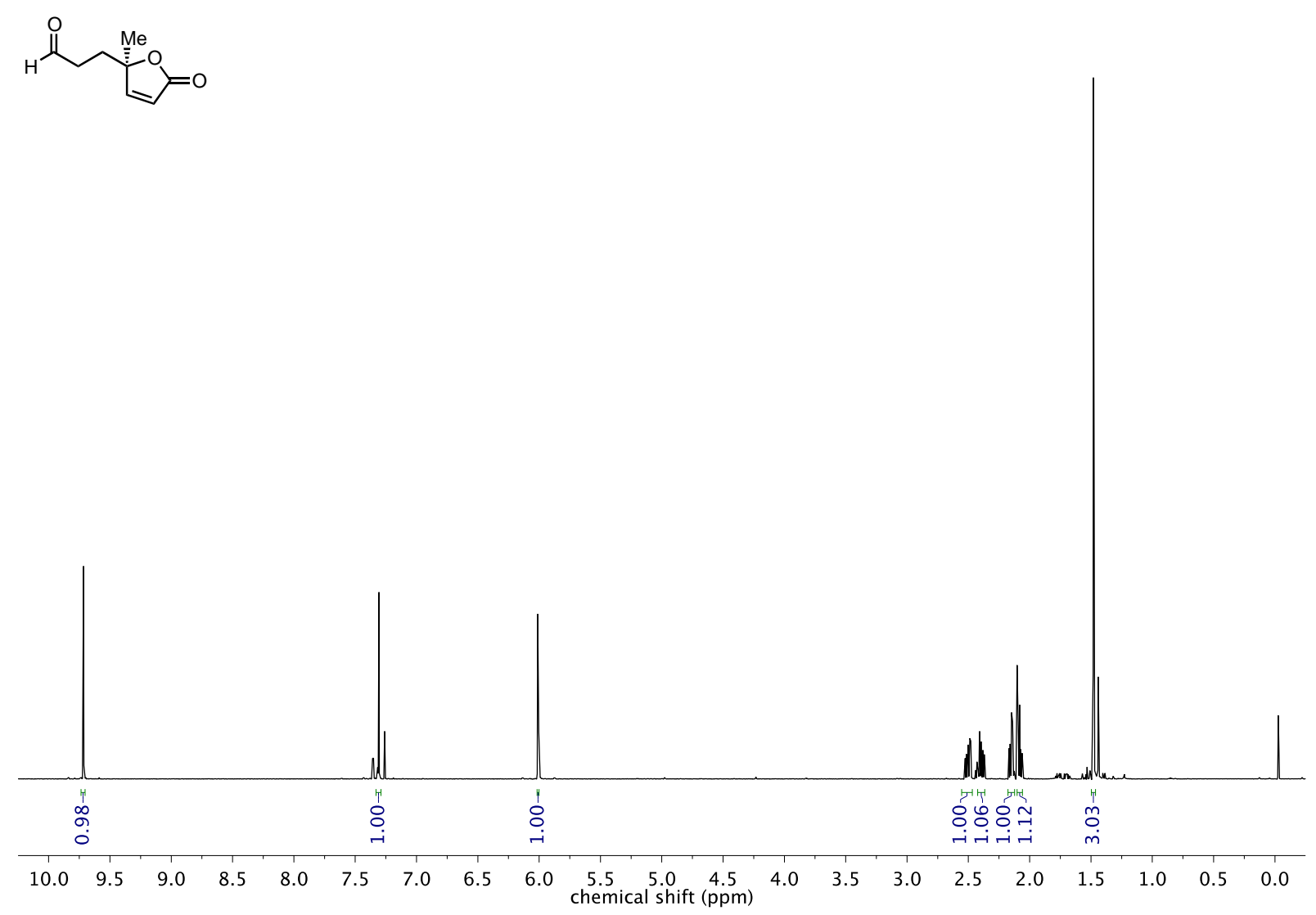

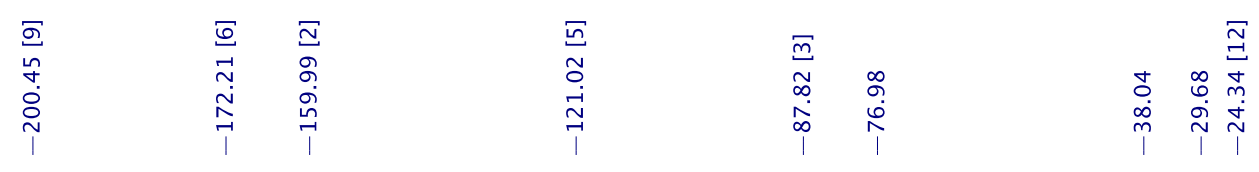

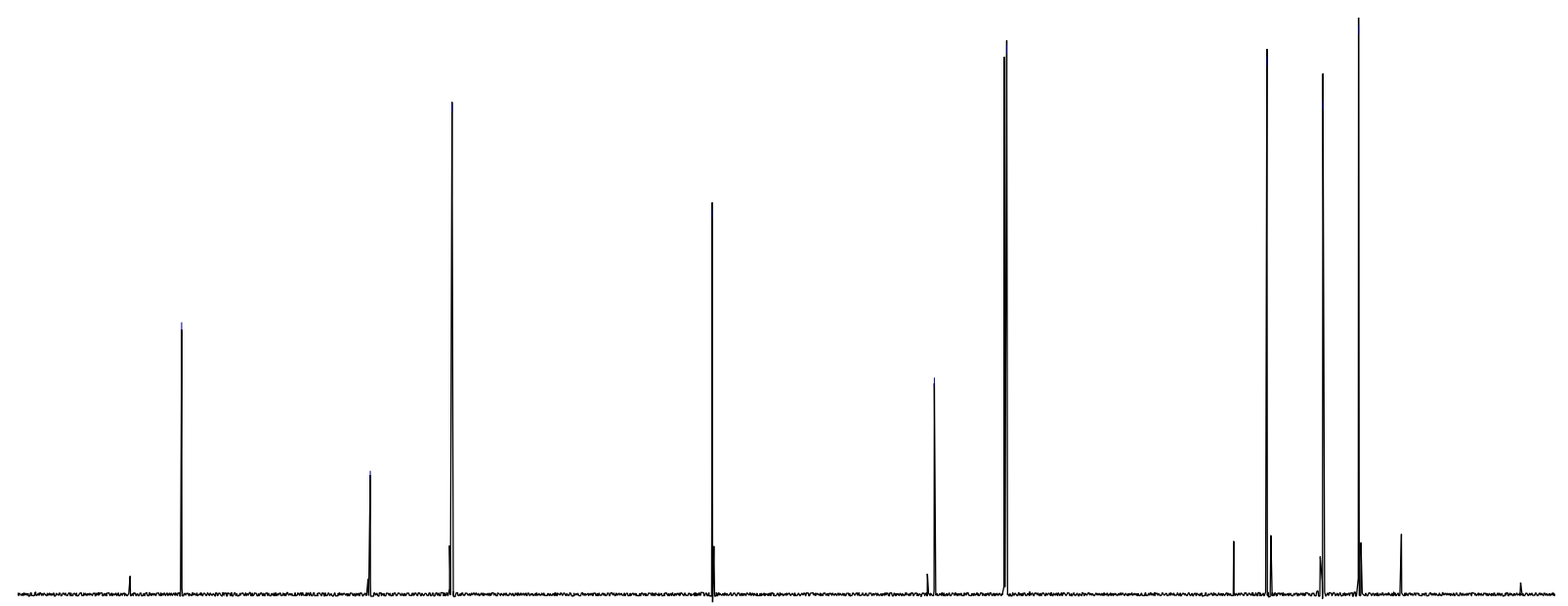

$\begin{array}{llllllllllllllllllllllll}220 & 210 & 200 & 190 & 180 & 170 & 160 & 150 & 140 & 130 & 120 & 110 & 100 & 90 & 80 & 70 & 60 & 50 & 40 & 30 & 20 & 10 & 0\end{array}$ 


\section{Enal SI-4}<smiles>C=C(C=O)C[C@]1([14OH])C=CC(=O)O1</smiles>

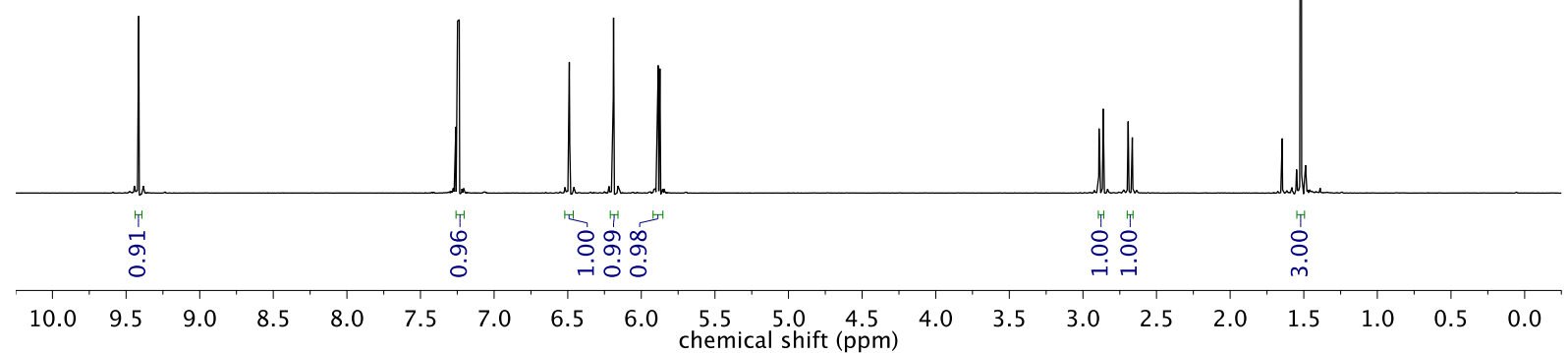

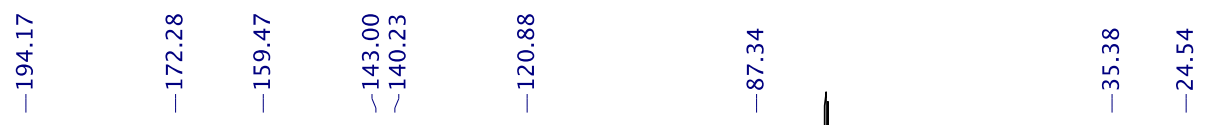

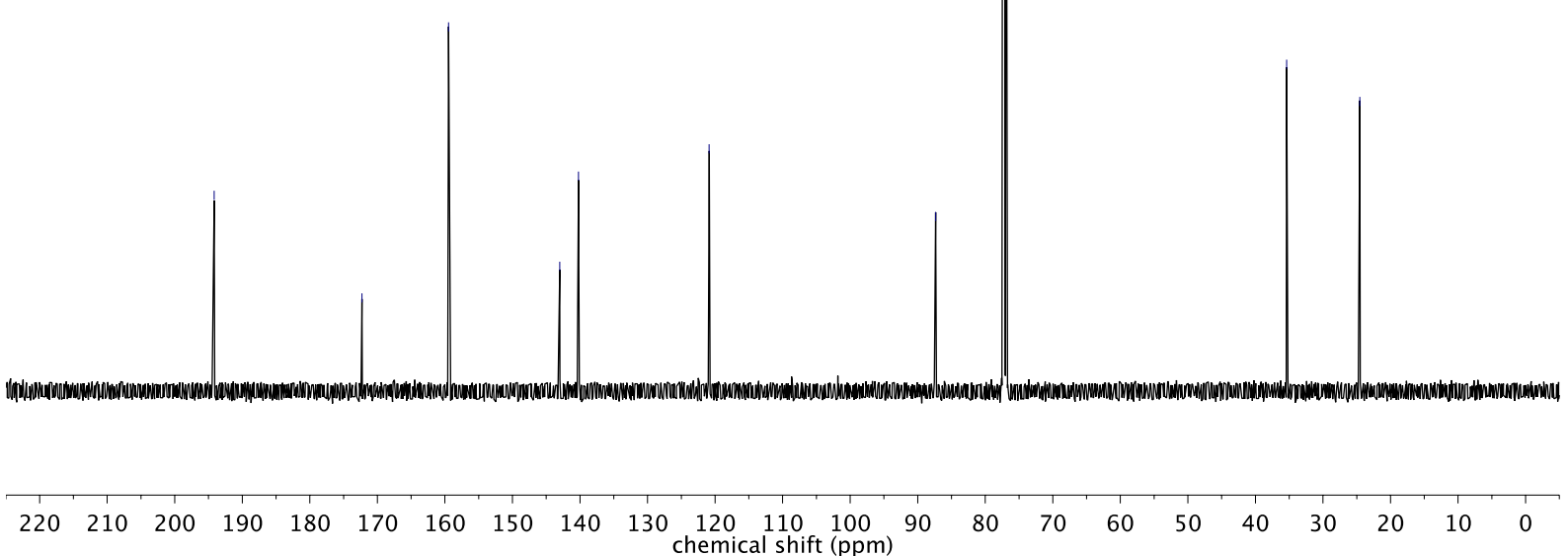


Allyl acetate 4

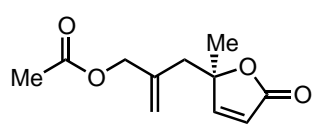

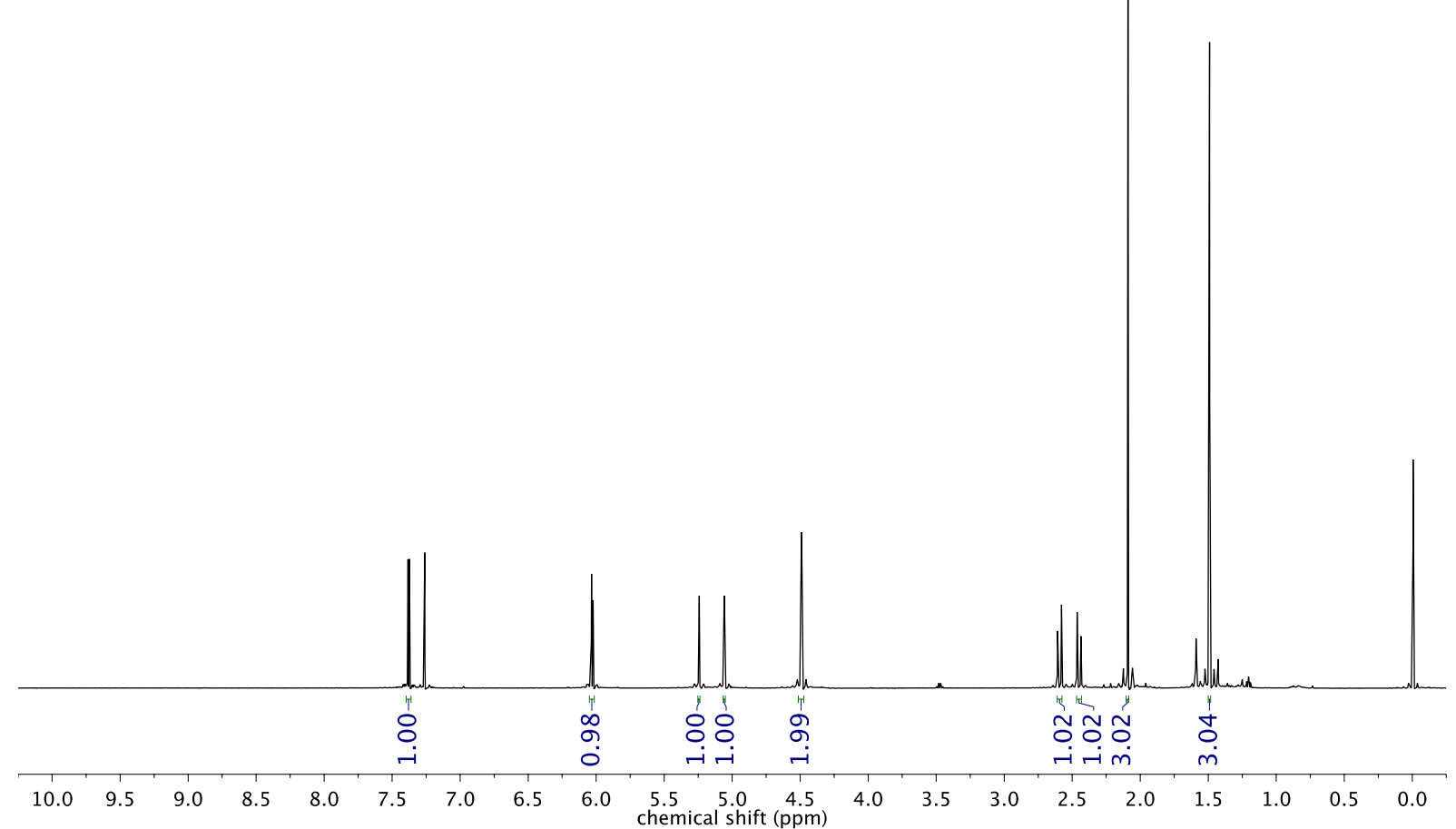

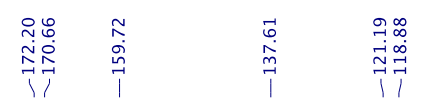

$\substack{a \\ 0 \\ \infty}$
1

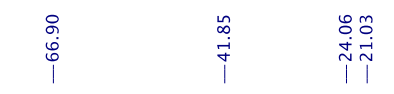

$\begin{array}{llllllllllllllllllllllll}220 & 210 & 200 & 190 & 180 & 170 & 160 & 150 & 140 & 130 & 120 & 110 & 100 & 90 & 80 & 70 & 60 & 50 & 40 & 30 & 20 & 10 & 0\end{array}$

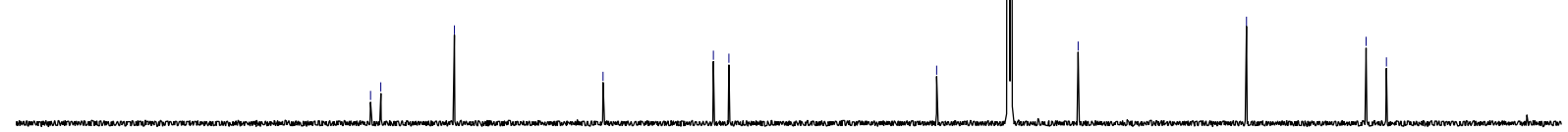
chemical shift (ppm) 


\section{Alkene 3}
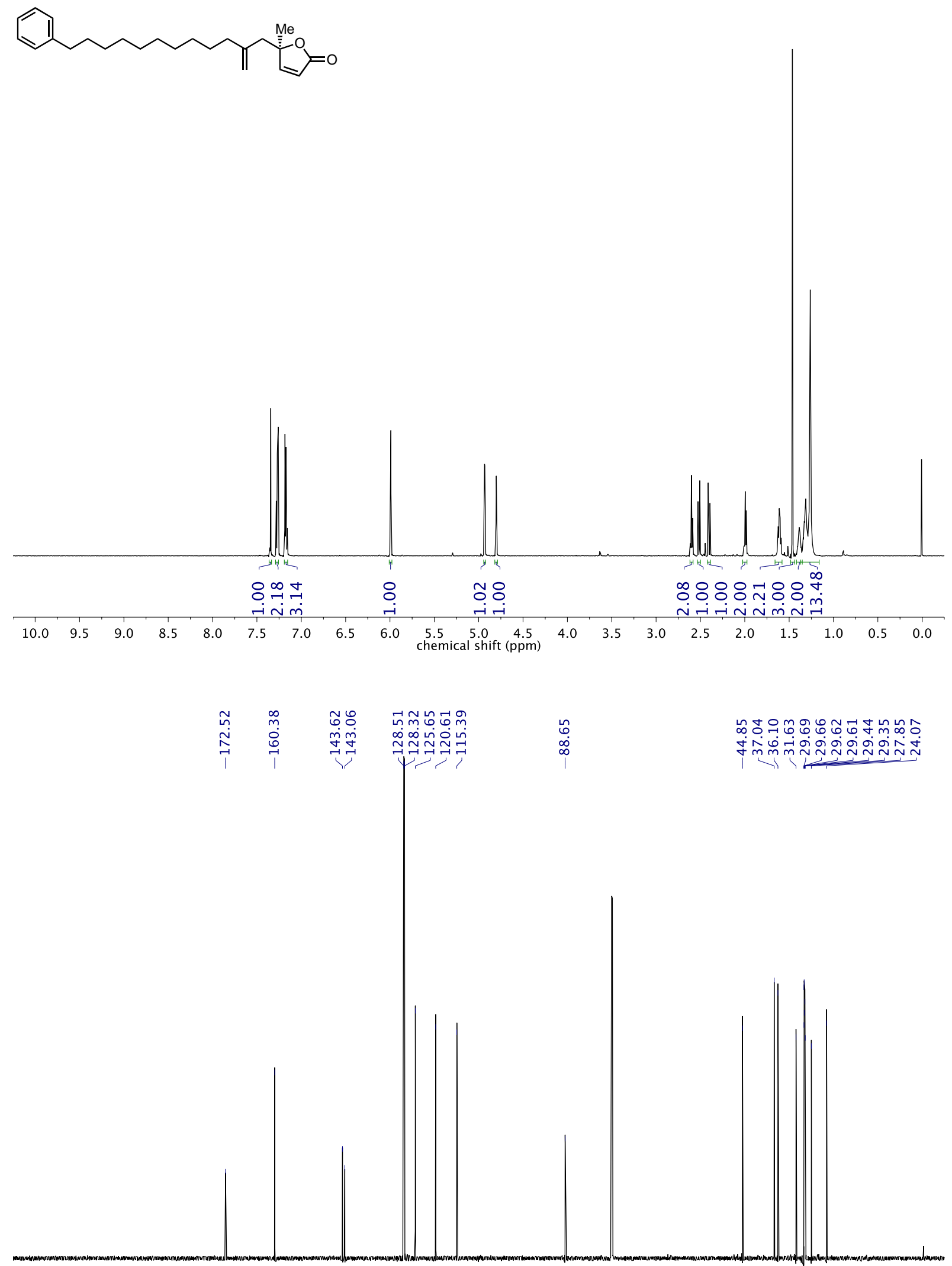

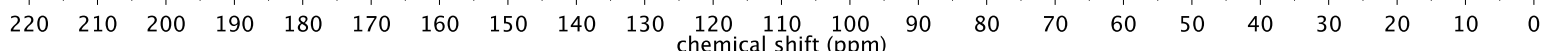


(+)-Plakortolide E (1)
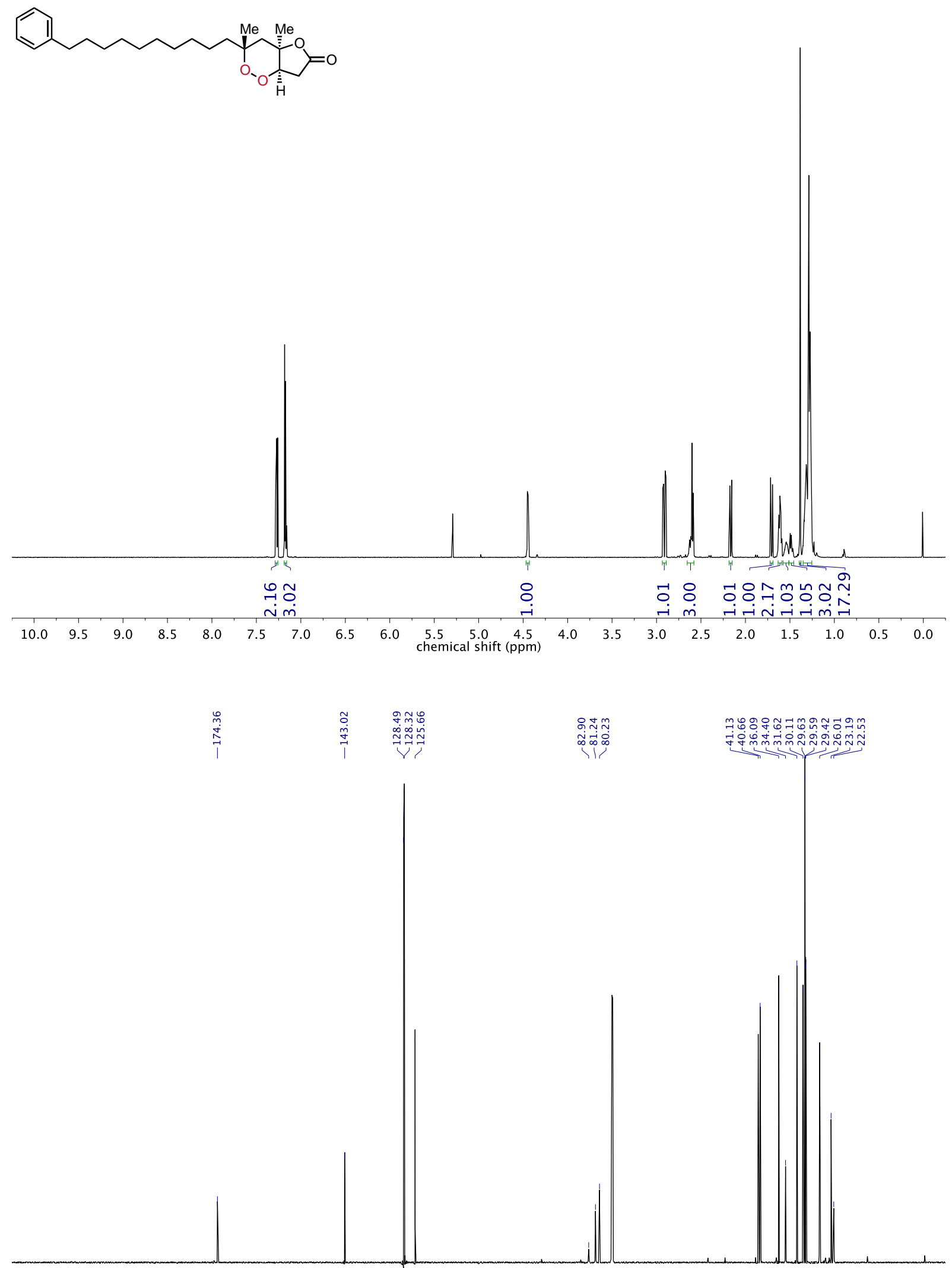

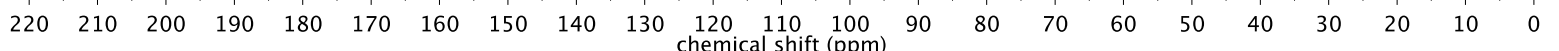


(-)-Plakortolide I (2)
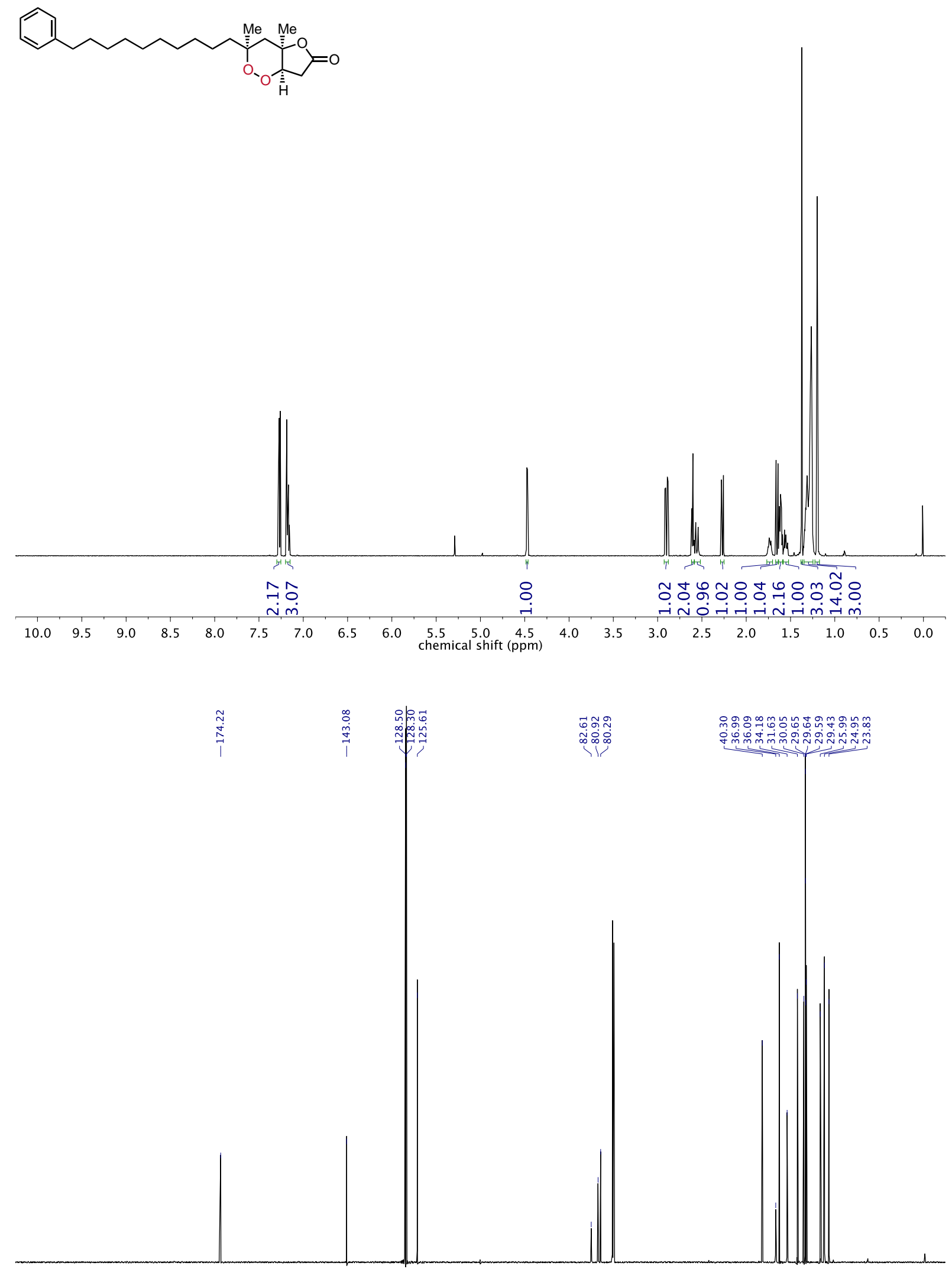

$\begin{array}{lllllllllllllllllllllll}220 & 210 & 200 & 190 & 180 & 170 & 160 & 150 & 140 & 130 & 120 & 110 & 100 & 90 & 80 & 70 & 60 & 50 & 40 & 30 & 20 & 10 & 0\end{array}$ 


\section{References}

(1) Langhanki, J.; Rudolph, K.; Erkel, G.; Opatz, T. Total synthesis and biological evaluation of the natural product (-)-cyclonerodiol, a new inhibitor of IL-4 signaling. Org. Biomol. Chem. 2014, 12, 9707-9715.

(2) Zeynizadeh, B.; Zahmatkesh, K. First and Efficient Method for Reduction of Aliphatic and Aromatic Nitro Compounds with Zinc Borohydride as Pyridine Zinc Tetrahydroborato Complex: A New Stable Ligand-Metal Borohydride. J. Chin. Chem. Soc. 2003, 50, 267-271.

(3) Chen, X.; Cheng, Z.; Guo, J.; Lu, Z. Asymmetric remote C-H borylation of internal alkenes via alkene isomerization. Nat. Commun. 2018, 9, 3939.

(4) Barnych, B.; Vatèle, J.-M. Total Synthesis of seco-Plakortolide E and (-)-ent-Plakortolide I: Absolute Configurational Revision of Natural Plakortolide I. Org. Lett. 2012, 14, 564-567

(5) Sheldrick, G. M. A short history of SHELX. Acta Cryst. 2008, A64, 112-122.

(6) Sheldrick, G. M. Crystal structure refinement with SHELX. Acta Cryst. 2015, C71, 3-8.

(7) Dolomanov, O. V.; Bourhis, L. J.; Gildea, R. J.; Howard, J. A. K.; Puschmann, H. OLEX2: a complete structure solution, refinement and analysis program. J. Appl. Cryst. 2009, 42, 339-341.

(8) Leisering, S.; Riaño, I.; Depken, C.; Gross, L. J.; Weber, M.; Lentz, D.; Zimmer, R.; Stark, C. B. W.; Breder, A.; Christmann, M. Synthesis of (+)-Greek Tobacco Lactone via a Diastereoablative Epoxidation and a SeleniumCatalyzed Oxidative Cyclization. Org. Lett. 2017, 19, 1478-1481.

(9) Siitonen, J. H.; Pihko, P. M. Total Synthesis of (+)-Greek Tobacco Lactone. Synlett 2014, 25, 1888-1890.

(10) Benohoud, M.; Erkkilä, A.; Pihko, P. M. ORGANOCATALYTIC $\alpha$-METHYLENATION OF ALDEHYDES: PREPARATION OF 3,7-DIMETHYL-2-METHYLENE-6-OCTENAL. Org. Synth. 2010, 87, 201-208.

(11) Zeynizadeh, B.; Setamdideh, D.; Faraji, F. Reductive Acetylation of Carbonyl Compounds to Acetates with Pyridine Zinc Borohydride. Bull. Korean Chem. Soc. 2008, 29, 76-80.

(12) Zhu, D.; Lv, L.; Li, C.-C.; Ung, S.; Gaom, J.; Li, C.-J. Umpolung of Carbonyl Groups as Alkyl Organometallic Reagent Surrogates for Palladium-Catalyzed Allylic Alkylation. Angew. Chem. Int. Ed. 2018, 57, 16520-16524.

(13) Lin, H.-S.; Paquette, L. A. A Convenient Method for Determining the Concentration of Grignard Reagents. Synth. Commun. 1994, 24, 2503-2506.

(14) Bernauer, J.; Wu, G.; Jacobi von Wangelin, A. Iron-catalysed allylation-hydrogenation sequence as masked alkyl-alkyl cross-couplings. RSC Adv. 2019, 9, 31217-31223.

(15) Rudi, A.; Afanii, R.; Gravalos, L. G.; Aknin, M.; Gaydou, E.; Vacelet, J.; Kashman, Y. Three New Cyclic Peroxides from the Marine Sponge Plakortisaff simplex. J. Nat. Prod. 2003, 66, 682-685.

(16) Qureshi, A.; Salvà, J.; Harper, M.; Faulkner, D. J. New Cyclic Peroxides from the Philippine Sponge Plakinastrella sp. J. Nat. Prod. 1998, 61, 1539-1542. 